\title{
Restoring in-stream habitat in urban catchments: modify flow or the channel?
}

Desmond O. Anim ${ }^{1}$, Tim D. Fletcher ${ }^{1}$, Geoff J. Vietz ${ }^{1}$, Gregory B. Pasternack ${ }^{2}$, Matthew J. Burns ${ }^{1}$

${ }^{1}$ Waterway Ecosystem Research Group, School of Ecosystem and Forest Science, The University of Melbourne, Burnley, Victoria 3121, Australia

${ }^{2}$ University of California Davis, Land, Air and Water Resources, Davis, CA, 95616, USA

Running Head: Restoring urban streams

\begin{abstract}
Urban streams have almost universally altered physical habitat conditions due to excess stormwater runoff. This includes changes to in-channel hydraulics and channel morphology. Restoration of in-channel habitat has two main levers: address the hydrology or channel morphology. Both variables impact in-stream habitat but understanding the relative role of hydrologic and morphologic change remains a challenge. This study uses two-dimensional hydraulic modelling to examine the relative roles of flow and channel morphology in setting hydraulic conditions. We investigated four test scenarios involving the combinations of urban versus natural hydrology and urban versus natural channel morphology. The analysis investigated three ecologically relevant hydraulics characteristics; bed mobilization, retentive habitat and floodplain inundation, using Shields stress, shallow slow-water habitat (SSWH) area and floodplain inundation area hydraulic metrics respectively. The results indicate substantial differences in hydraulic conditions between the two reaches. The urban reach showed increased bed mobility potential and SSWH availability plummeted as flow increased, whereas the natural channel showed a relatively stable bed with substantially more SSWH at most flows. Floodplain inundation frequency was low in the urban channel with decreased duration. Scenarios examined suggest hydraulic conditions are highly sensitive to channel morphology relative to flow regime. This suggests that once channel form has been degraded, mitigating urbanization impacts on flow regime cannot maintain 'natural' channel hydraulics. Management approaches therefore must protect channel morphology from

This is the author manuscript accepted for publication and has undergone full peer review but has not been through the copyediting, typesetting, pagination and proofreading process, which may lead to differences between this version and the Version of Record. Please cite this article as doi: 10.1002/eco.2050
\end{abstract}

This article is protected by copyright. All rights reserved. 
change. Where the channel has already been fundamentally altered, opportunities for channel morphology rehabilitation needs to be considered.

Keywords: Stream hydraulics; flow regimes; channel morphology; urbanization; twodimensional modelling, stream restoration, instream habitats.

\section{INTRODUCTION}

Urbanization impacts hydrological processes, sediment supply and nutrients flux, leading to major changes in stream ecosystems such as flow regime and channel morphology alteration, and water quality impairment (Wenger et al., 2009; Vander Laan et al., 2013). These impacts lead to poor ecological condition (Walsh et al., 2005b). Stream management and restoration efforts involving direct interventions have focused on local channel stability, including channelization (Bernhardt et al., 2005; Vietz et al., 2015) and improving in-stream habitat (Violin et al., 2011; Brown \& Pasternack, 2017). The latter is characterised by creating specific habitat characteristics to meet perceived "better" habitat conditions or standards (Paul \& Meyer, 2001; Chin \& Gregory, 2009). Ideally, designs seek to re-institute key process-morphology mechanisms (Wheaton et al., 2004). Unfortunately, such actions require major effort and expense to implement (Bernhardt et al., 2005). This is particularly the case for stream draining substantially urbanized catchments (Bernhardt \& Palmer, 2007; Walsh et al., 2012). In addition, most engineered efforts of instream morphological adjustment are done with little or no ecological criteria consideration (Miller \& Kochel, 2010; Bernhardt \& Palmer, 2011. In other words, mimicking reference natural in-stream habitat are done with lack of sufficient goals for both morphological self-sustainability and ecological functions which limit the chances of any ecological gains (Gurnell et al., 2007; Violin et al., 2011).

There have been recent calls for more holistic strategies that move towards process-based restoration (Beechie et al., 2010). At the core of the process-based restoration approach is the aim to address the root causes of ecosystem degradation rather than the symptoms (Beechie et al., 2010; Fletcher et al., 2014). This approach aims to re-establish linked hydrogeomorphic and biological processes that create and sustain the natural ecosystem (Beechie \& Bolton, 1999; Pasternack, 2008). The process-based approach expresses a broader effort that include 
specific hydrological, geomorphological and ecological objectives. These are the underlying key drivers of ecosystem degradation along a recovery trajectory. Notably, process-based restoration must address multiple spatial scales (e.g. catchment, sub-catchment reach, segment, reach and sub-reach) (Beechie et al., 2010; Palmer et al., 2014; Walsh et al., 2016).

There is wide recognition that sustainable urban stream restoration requires the catchmentscale flow regime to be addressed. In the urban setting particularly, the goal is to minimize and attenuate excess stormwater runoff (Ladson et al., 2006; Wenger et al., 2009), such that the altered flow regime can be restored towards pre-development levels as a means to reestablish linked hydrogeomorphic and biological processes that create and sustain the natural ecosystem functioning (Vander Laan et al., 2013; Walsh et al., 2015; Burns et al., 2016). This is based on the synthesis of recent literature that argues based on empirical and theoretical evidence that altered flow regimes driven by urban stormwater runoff input is a key degrader of stream ecosystems (Wenger et al., 2009; Walsh et al., 2012; Burns et al., 2013; Vietz et al., 2014; Hawley \& Vietz, 2016). In this regard, urban stream degradation has been considered largely as a hydrological problem (Ladson et al., 2006; Walsh et al., 2012). This has led to calls for a catchment-scale mitigation of hydrologic disturbance to address urban stream impairment (Burns et al., 2013; Loperfido et al., 2014; Askarizadeh et al., 2015). It is argued that, this management approach is necessary to restore the water quality and hydrological regimes needed to support healthy streams (Fletcher et al., 2014; Vietz et al., 2016; Walsh et al., 2016).

Ultimately, to improve stream health, it is necessary to set restoration objectives that are directly linked to the needs of the receiving stream ecosystem, considering both hydrogeomorphic linkages and biological processes. Restoration strategies could have a better chance of leading to ecological benefits when the approach is based on the mechanistic relationships between flow and channel form (Clark et al., 2008; Yarnell et al., 2015). While flow is key, the intermediate mechanisms by which a total amount of water (i.e. the flow) interacts with the stream's boundary to be translated into different hydraulic components, such as depths and velocities, is critical to the success of any flow manipulation. These components, not the flow alone, drive the stream ecosystem functions (Emery et al., 2003; 
Wallis et al., 2012). Ecologists and river scientists generally recognize that physical hydraulic conditions form one of the key coordinating template for aquatic ecosystem processes (Statzner et al., 1988; Townsend et al., 1997a; Järvelä \& Helmiö, 2004). It is these hydraulic conditions that sediments (Gibbins et al., 2007) and biota (Statzner \& Higler, 1986; Jowett, 2003) experience and relate to. They have been documented to largely drive their distribution via ecological disturbance (Kemp et al., 2000; Brooks et al., 2005; Gibbins et al., 2007; Anim et al., 2018a).

Therefore, it is important that restoration approaches result in suitable hydraulic conditions as an intermediate 'indicator' between source catchment hydrology and ultimate ecological functions. In attempts to manage flow regimes and rehabilitate channel form for ecological benefits, there is the need to understand how these two separate (but interacting) actions alter the hydraulic regime. That the patterns of the hydraulic template are often used to speculate the mechanisms influencing ecosystem functioning points to the importance of exploring it as a mechanistic platform for examining how addressing these two main levers towards restoration could impact ecological gains.

This study explores two questions. First, could restored catchment hydrology imposed on a fundamentally degraded channel morphology result in ecologically suitable hydraulic conditions? Alternatively, could restoring degraded channel morphology be enough to mitigate the degrading effect of altered flow regimes on the hydraulic conditions in a substantially urbanized catchment? Our study aims to provide a better understanding of the likely consequences of changes to channel morphology and flow regimes as independent actions aiming to restore a degraded urban stream. It provides information on the relative merits of channel and hydrologic restoration, given that in many cases constraints may limit the feasibility of one or the other approach.

\section{METHODS}

\subsection{Experimental design}

To answer the above questions, the experimental design involved two-dimensional (2D) hydraulic modelling of two sites to compare and contrast the relative effects of channel 
morphology and flow in setting hydraulic conditions. Specifically, the study compared the hydraulics in urban and natural reaches of the same stream by investigating different hydrogeomorphic scenarios. Each scenario aims to represent the current condition in the urban and natural state as well as conceptually test the management approach of either restoring flow or morphology. We characterized the hydraulic change using three ecologically relevant hydraulic metrics (details presented in a later section). These metrics describe the dynamics of channel bed disturbance (bed particle entrainment), physical habitat availability and hydrologic connectivity between stream channels and floodplains and are of known link to relevant which are important for aquatic ecosystem functions (McCabe \& Gotelli, 2000; Paterson \& Whitfield, 2000; King et al., 2003; Brooks et al., 2005).

Data was collected from the sites to characterize site topography, hydrology and hydraulics to perform 2D modelling, including model calibration and validation.

\subsection{Study sites}

The study sites were those investigated in a previous study by Anim et al. (2018) (Figure 1). Site selection aimed to physically represent and compare urban and natural settings, referred herein as 'urban' and 'natural' reaches respectively. The urban reach, located $6 \mathrm{~km}$ downstream of the natural reach has a simplified low-gradient, sand-gravel bed $\left(\mathrm{d}_{50} \sim 6 \mathrm{~mm}\right)$ channel morphology and exhibits less complexity both in cross-profile and planform (Table 1). The natural reach has a relatively intact and complex naturally meandering channel with a sand-gravel bed $\left(\mathrm{d}_{50} \sim 3 \mathrm{~mm}\right)$, pool-riffle morphology, depositional sediment benches and point bars. Both sites have similar rainfall pattern, with an annual catchment rainfall averaging $\sim 950 \mathrm{~mm} /$ year. Rain is fairly evenly distributed over the year with a spring-winter bias. Most streams in this catchment flow perennially. Further sites details are given in Supplementary Material.

\subsection{Data Collection}

\subsubsection{Channel topography}

Detailed site topographic surveys followed steps reported by Anim et al. (2018). The particle size distribution of bed materials was determined using Wolman pebble counts performed 
randomly in riffles and runs at low flows (Kondolf \& Li, 1992). A representative median size $\left(d_{50}\right)$ was extracted showing a sand-gravel bed channel morphology for each reach.

\subsubsection{Hydrology}

For each site, water levels were recorded continuously at 6-min interval using ODYSSEY capacitive level sensor from January 2015- December 2016. The level data were converted to streamflow using stage-flow rating curves specifically determined for the two study reaches based on direct gauging. For each discharge gauging, water surface elevation (WSE) longitudinal profiling was performed at $20 \mathrm{~m}$ intervals along both banks for each reach. In addition to observed flows, this study made use of estimated flows (January 2008 December 2014) using the continuous 6-mins streamflow record from a nearby Melbourne Water stream gauging station $228382 \mathrm{~A}$ on the Cardinia Creek, $\sim 6 \mathrm{~km}$ downstream of the urban reach (Figure 1). McMahon et al. (2002) approach of estimating streamflow for an ungauged site was used by establishing a relationship between measured streamflow (20152016) and the Melbourne Water gauge data for the same period (see Supplementary material for relationships between sites and the gauge). Methods used to establish this relationship are detailed in McMahon et al. (2002). This study thus uses the January 2008 to December 2016 water years' data (Figure 2) providing a good representation of typical dry, normal and wet year conditions. Further hydrologic detail is provided in Supplementary Materials.

\subsection{Hydraulic modelling}

TUFLOW hydraulic model that solves the full 2D (depth-averaged) momentum and continuity equations for free surface flow (Syme, 2001) was used for the simulations. A 0.3m square grid computational mesh was elevated with the topo-bathymetric survey data for each reach. The domain extended $20 \mathrm{~m}$ beyond the region of interest, both upstream and downstream, to minimize the impact of flow and boundary assumptions on model outputs within the region of interest. Model simulation input and boundary conditions included inflow streamflow time series and corresponding downstream WSE. Unsteady models were run spanning the representative flow ranges for the hydrological data corresponding to 0.5-99 $\%$ of time discharge (Q) exceedance. This represents 0.05-6 and 0.02-3 times bankfull 
discharge $\left(\mathrm{Q}_{\mathrm{bkf}}\right)$ for the natural and urban site, respectively. Model outputs include WSE, water depth, bed shear stress $\left(\tau_{o}\right)$, and depth-averaged velocity in the direction of flow.

\subsection{Modelling scenarios}

Four different hydrogeomorphic scenarios were explored using channel morphology and flow regime as shown in Figure 3. Scenario CnatQnat and CurbQurb represents the current condition in the natural and urban reach where natural hydrology (Qnat) was modeled in the natural channel (Cnat) and urban hydrology (Qurb) was modeled in the urban channel (Curb), respectively. Scenario CurbQnat tested whether restored hydrology within a fundamentally degraded channel morphology could result in ecologically important hydraulic conditions. Scenario CnatQurb tested whether just restoring degraded channel morphology could results in maintaining hydraulic conditions at levels likely to sustain ecosystem functioning particularly where managing flows are constrained. In other words, scenario CurbQnat and CnatQurb conceptually represent management approach of either restoring flow or morphology, individually.

\subsection{Model calibration and validation}

For calibration purposes, initial steady-state model runs were conducted for observed flows ranging from 0.04-1.57 and 0.04-0.97 for the urban and natural reaches respectively. The models were calibrated for both reaches by adjusting Manning's $n$ values to match observed WSE. Then, model validation was performed using measured, independent fixed-point depth and velocity sampled by wading at the same flows. This was done by comparing quantitatively the predicted verses observed values. Calibration and validation approach and metrics as well as their threshold values are detailed in the Supplementary Material.

\subsection{Hydraulic test variables}

Bed shear stress, velocity and water depth model outputs were used to evaluate each studied scenario in keeping with previous studies that have investigated their relevance to stream ecosystem functioning (Brooks et al., 2005; Gibbins et al., 2007; Sawyer et al., 2010; Vietz et al., 2013; Shearer et al., 2015). In this study, the ecologically relevant hydraulic metrics used to characterize the hydraulic change include: Shields stress, slow-shallow water habitat 
(SSWH) area and floodplain inundation area. In most aquatic ecosystem flow investigation, the spatial and temporal variabilities of these hydraulic conditions have been closely linked to the ecological condition (Humphries et al., 2006; Vietz et al., 2013) as well as geomorphic processes (Strom et al., 2016). The bed shear stress is usually examined to investigate refuge concept for benthic space available as refugia where magnitude and duration of shields stress above a specific threshold are used to assess possible disturbance of benthic biota from bed movement (Jorde \& Bratrich, 1998; Mérigoux \& Dolédec, 2004). SSWH availability within the wetted channel has primarily been investigated which is mostly essential determinant of species population dynamics (Gibbins et al., 2007; Lobera et al., 2017). Extinction of this habitat has been shown to reduce fish abundance, macroinvertebrates that depend on them as refugia and organic matter retention (Vietz et al., 2013). In addition, the duration and frequency of floodplains inundation have been linked with a flow-mediated exchange of energy, organic matter and biota (Cienciala \& Pasternack, 2017). Floodplains flow dynamics provide key habitat supporting biota such as fish utilizing it as spawning and rearing habitat (Gorski et al., 2011).

Non-dimensionalized Shields Stress $\left(\tau^{*}\right)$ was estimated from TUFLOW's bed shear stress output in each grid cell as:

$$
\tau *=\frac{\tau_{o}}{\mathrm{~d}_{50}\left(\gamma_{s}-\gamma_{w}\right)}
$$

where $\gamma_{s}$ and $\gamma_{w}$ are the unit weight of bed material and water respectively. This was analysed to compare the two reaches for their relative potential for bed particle entrainment (Pasternack, 2011) using a critical entrainment threshold $\left(\tau_{c}^{*}\right)$ of 0.045 (Lisle et al., 2000; Sawyer et al., 2010). The SSWH area evaluates the relative retentive habitat availability. This was estimated using a decision tree in ArcGIS (Esri ArcGIS desktop 10.2) that searched depth and depth-average velocity outputs to locate areas with a depth class of $0-0.3 \mathrm{~m}$ and velocity class of $0-0.2 \mathrm{~ms}^{-1}$. This depth and velocity combination is particularly preferred by benthic macroinvertebrates (Shearer et al., 2015) and fish (Smith, 1973; Milhous \& Nestler, 2016) in small streams. Floodplain inundation area analysis involved simulations that 
exceeded $\mathrm{Q}_{\mathrm{bkf}}$. This was estimated as the difference between the total inundated area in the model output and the wetted area of the bankfull flow simulation for each reach.

\subsection{Data analysis}

The initial step in data analysis involved developing a functional relationship between flow and each hydraulic metrics explored. Model simulations for the full range of flows in the urban and natural reach hydrological records provided the data to do this. The annual time series for the study period was then parsed into the investigated scenarios for evaluation. The Continuous Above Threshold (CAT) time series analysis approach was used to analyse test variables for continuous events above many incrementally higher or lower thresholds (Castelli et al., 2011). This approach was employed together with simple descriptive statistics in relation to stream ecosystem functioning where the continuous nature of certain hydraulic conditions is critically relevant. The CAT procedure was applied here to the Shields stress and floodplain inundation area.

The relative influence of the channel morphology and altered flow regimes were evaluated by quantitatively characterizing and comparing the relative change in the hydraulic regime. This was assessed by the increase or decrease of the test variables as a function of discharge relative to the investigated scenarios. The statistical analysis of the time series of each variable aimed to examine the various aspects of the hydraulic patterns: magnitude, duration and frequency between the two reaches for each scenario. The degree of change was tested corresponding to a threshold value. For example, the level of bed disturbance was assessed relative to the bed material entrainment threshold for Shields stress (i.e, 0.045). SSWH and floodplain inundation was assessed by the relative percent total area of availability and area of inundation respectively per $100-\mathrm{m}$ reach length.

\section{RESULTS}

\subsection{Model performance}

Model validation tests performed on mass conversation, WSE, depth and velocity magnitude were deemed acceptable to common standards reported (e.g. Moriasi et al., 2007; Pasternack, 
2011). Compared predicted and observed depth and velocity values showed satisfactory model performance. Results are provided in Supplementary Materials.

\subsection{Shields stress patterns}

The $\tau^{*}$ time series pattern for each modelled scenario (Figure 4 ) shows the bed disturbance regime between the reaches. At very low flows particularly during summer periods, the $\tau^{*}$ patterns appear similar for all scenarios but then differ substantially as flow increases. In all, monotonic increases of $\tau^{*}$ as flow increased were observed but at a higher rate in the urban channel, whereas relatively marginal increases were observed in the natural channel.

The natural channel (CnatQurb and CnatQnat) showed comparatively stable beds with a low potential of bed entrainment. These scenarios had an average $\tau^{*}$ of 0.015 and 0.039 during baseflow and recession periods respectively. In the urban channel, $\tau^{*}$ was greatest for CurbQurb, with persistent spikes particularly during runoff periods in the winter, resulting in the most unstable bed with a high likelihood of frequent bed entrainment. The average $\tau^{*}$ at storm flows was 0.062 as flow peaks, which then averages at 0.02 and 0.042 throughout baseflows and recession periods, respectively. For natural hydrology in urban channel, $\tau^{*}$ averages at 0.052 as flow peaks for storm flows and 0.018 and 0.04 during baseflows and recession periods respectively. Shield stress averages 0.048 and 0.04 in the natural channel for urban and natural hydrology, respectively, at the peak of storm flows. High $\tau^{*}(>0.05)$ in the urban channel were usually associated with flows between 0-35\% and 0-10\% exceedance for urban and natural hydrology respectively. For the natural channel, almost all high $\tau^{*}$ were associated with flows between $0-15 \%$ and $0-4 \%$ exceedance urban and natural hydrology respectively.

The frequency of bed disturbance over the study period was found to be substantially greater in the urban reach. The period that daily $\tau^{*} \geq \tau_{c}^{*}$ was 890 days during total study period with an average of 98 days/year for urban hydrology and 335 days for natural hydrology, averaging 37 days/year. The natural hydrology in the urban channel resulted in $15 \%$ decrease in the total number of days $\tau^{*} \geq \tau_{c}^{*}$. Also, above $\tau_{c}^{*}$ days in the natural channel was 250 days 
for the urban hydrology and 67days for natural hydrology corresponding to about $7.5 \%$ and $2 \%$ of the total study duration, respectively.

The CAT analysis allowed the comparison of the modelled scenarios that considers continuous duration above $\tau_{c}^{*}$ (Figure 5) over the study period. The influence of a larger proportion of frequent storm flows as well as the channel topography is reflected in the continuous above $\tau_{c}^{*}$ duration. For example, comparing the urban and natural hydrology in the urban channel, the frequency (number of days) of CAT duration particularly above 10 days for the urban hydrology was $\sim 12 \mathrm{x}$ that of the natural hydrology. This represents $\sim 21 \%$ of the total number of CAT period compared to $2.2 \%$ for the urban and natural hydrology respectively, reflecting the increased frequency-high magnitude storm flows in the urban hydrology. In addition, the frequency of CAT duration above 10 days for urban hydrology in the urban channel was $\sim 24 \mathrm{x}$ that of urban hydrology in the natural channel. This was observed to be in excess of 12 occurrences within the duration class of 15-30 continuous days mostly during winter period. Here, the relative difference between above $\tau_{c}^{*}$ days for in the urban channel were larger for long duration-high magnitude events. Similarly, the natural hydrology in the urban channel resulted in reduced frequency of CAT duration particularly above 10 days (Figure 5). The highest CAT duration in the natural channel being 5 days. In other words, the relative differences reflect the influence of the channel morphology on the bed disturbance regime.

\subsection{Habitat retention patterns}

Changes to SSWH area with flows showed similar trends for both reaches (Figure 6). Generally, SSWH area was high at low flows ( 0.06-0.15x $\left.\mathrm{Q}_{\text {bkf }}\right)$ for both reaches. The inundation of higher-level lateral bars and benches resulted in a rapid increase in SSWH as flow approached $\mathrm{Q}_{\mathrm{bkf}}$ in the natural channel morphology, regardless of hydrology. The presence of a gradually changing channel topography in the natural reach ensured abundant SSWH area. In contrast, in the urban channel, as flow and velocity increased, the plane channel bed is more uniformly inundated to greater depths, so SSWH area showed a general decline. Here, rapid declines in SSWH occurred at moderately high flows associated with the 
rising and falling limbs where the flow was deeper and faster with considerably reduced SSWH within the channel.

At very low flows particularly in the summer, corresponding to flows between $80-95 \%$ exceedance, SSWH area averages $80 \mathrm{~m}^{2} / 100 \mathrm{~m}$ of the wetted area in the urban channel (CurbQurb and CurbQnat) compared to about $50 \mathrm{~m}^{2} / 100 \mathrm{~m}$ in the natural channel. The maximum SSWH area varied from 170 to more than $300 \mathrm{~m}^{2} / 100 \mathrm{~m}$ in the natural channel and from 200 to over $500 \mathrm{~m}^{2} / 100 \mathrm{~m}$ in the urban channel. The natural hydrology in the urban channel (CurbQnat) increased the average SSWH area to $\sim 10 \%$, where mean annual total SSWH area increased by $\sim 13 \%$. Similarly, about 15 and $20 \%$ increases in the average SSWH area and mean annual total SSWH area respectively, were observed for the urban hydrology in the natural channel compared to the natural hydrology in natural channel.

Comparing the frequency distribution of SSWH availability per unit $100 \mathrm{~m}$ over the study duration showed a reduction in the frequency of larger areas of SSWH $\left(>200 \mathrm{~m}^{2} / 100 \mathrm{~m}\right)$ in the urban channel (CurbQurb and CurbQnat) (Figure 7). The daily values showed diversity in SSWH area is prominent in the natural channel (CurbQnat and CnatQurb) with frequent large areas of SSWH patch. Smaller SSWH areas $\left(<100 \mathrm{~m}^{2} / 100 \mathrm{~m}\right)$ were predominantly common in the urban channel particularly under low flow conditions. Overall, considerable reductions in SSWH availability was observed in the urban channel relative to the natural channel. The natural channel showed higher temporal persisting availability of SSWH compared to the urban channel over the entire study duration.

\subsection{Floodplain inundation patterns}

Floodplain inundation patterns reflected the relative difference between reaches with distinct topographic controls. A general trend of progressive increase in inundated area per unit flow was observed in the natural channel compared to the urban channel (Figure 8).

The results demonstrated that the average relative percent area of inundated floodplain in the urban channel for urban hydrology (CurbQurb) was about $25 \%$ of that for the natural channel with the same hydrology (CnatQurb). Similarly, the inundated floodplain area in the urban channel for natural hydrology (CurbQnat) was about 5\% of that for natural channel 
(CnatQnat). For flows, just above the $\mathrm{Q}_{\mathrm{bkf}}$, the inundated area in the natural channel was about $2 \mathrm{x}$ that in the urban channel and as much as about $4 \mathrm{x}$ for peak flows ( $>1.5 \mathrm{x}$ Qbkf). The morphological differences were reflected such that on average, for a given flow, inundated area in the natural reach was about $3 x$ that of the urban area. This effect is controlled by the increased channel capacity in the urban reach that would require extremely high flow to inundate the floodplain. As such, the floodplain is not accessed at most flows. The large extended floodplain space in the natural reach allowed substantial portion of larger area of shallow floodplain flow compared to a restricted floodplain space in the urban reach which confined the overflow to a limited inundation width.

In addition, the estimated continuous days of inundation analysis (Figure 9a) enabled the comparison of the reaches in terms of the duration of inundation for each scenario. The results showed an increased continuous duration of inundation in the natural channel compared to urban channel, revealing the influence of increased frequency and magnitude of peak flows in urban hydrology as well as morphological differences between the urban and natural channel. For example, urban hydrology in the natural channel increased the continuous duration of inundation particularly above 7 days. The duration of inundation is greater (> 3days) in the natural channel particularly for long duration-high magnitude events, compared to the urban channel where most inundation events lasted for just one day. Also, the between reach differences revealed that natural hydrology in the urban channel reduced the frequency of inundated floodplain by about $65 \%$, whereas urban hydrology in natural channel (CnatQurb) increased the frequency of inundation by $\sim 75 \%$ (Figure $9 b$ ). Urban hydrology in natural channel showed almost identical frequency of inundation to natural hydrology in natural channel. However, $\sim 5 \%$ increase in frequency of inundation at the natural channel was observed under urban hydrology particularly under a wet year condition (2010 -2012). In general, while the duration and magnitude of inundation vary annually in the natural reach, some degree of floodplain inundation is observed to occur with close to annual regularity. 


\section{DISCUSSION}

\subsection{Impact on bed disturbance regimes}

The introduction of urban hydrology into the natural channel (CnatQurb) led to a significant decrease of up to $\sim 60 \%$ in the frequency of likely bed entrainment compared to the current urban condition (CurbQurb). Contrary to our expectations, having natural hydrology in the urban channel yielded only a small reduction in bed disturbance regimes rates with frequency and duration somewhat reduced compared to urban hydrology in the urban channel.

These findings provide important insight into the relative contribution of the flow regime and channel form in an urban setting. Once already degraded, channel form acts as a dominant control of the potential bed disturbance regime, essentially limiting the expected benefits of plummeted bed disturbance when flow-regime is restored.

Conversely, natural topographic variability could provide the opportunity to reduce the streambed area subjected to high $\tau^{*}$ with increasing flows, which in turn ensures a more natural rate of bed entrainment. Strom et al. (2016) reported that channel form heterogeneity directs flow such that varying topographic surfaces turn on and off in their control of hydraulics to allow diverse patterns of hydraulic conditions as flow increases (Brown \& Pasternack, 2014; Brown et al., 2016). This is also consistent with studies recognizing that dynamic channels provide a greater opportunity for more natural rates of bed particle transport, erosion and deposition (Clarke et al., 2003; Vaughan et al., 2009; Vietz et al., 2016, Anim et al., 2018b).

Modelled results showed that the urban reach would likely experience substantially higher bed particle entrainment, which could potentially make the channel bed unstable. At storm flows $\left(<0.4 \mathrm{Q}_{\mathrm{bkf}}\right), \tau^{*}$ generally averages 0.062 in the urban reach, where an overturn of the bed is expected, a phenomenon Sawyer et al. (2010) referred to as "full transport" (i.e., persistent movement of a sheet of bed particles). Given that urban hydrology is particularly characterized by increased frequency, magnitude and volume of storm flows, we anticipate an acceleration in the channel bed particle entrainment. This expected increase in bed entrainment potential will successively increase movement efficiency of the channel and 
regularly adjust the physical habitat or cause habitat loss (Francoeur \& Biggs, 2006; Djekovic et al., 2016). In contrast, the natural reach predominantly retained low $\tau^{*}$, making the channel relatively stable with low potential of full bed particle transport even in storm flows. This evidence is consistent with past studies reporting that benthic space available as refugia in urban or modified aquatic systems becomes vanishingly small, particularly when spate occurs (Negishi et al., 2002; Finstad et al., 2007). It is generally known that channel beds dynamically adjust to varying sediment loads (Montgomery et al., 1999; Chang, 2008). However, the peak $\tau^{*}$ values experienced by the urban channel during storm flows will accelerate bed mobility in the channel even with high sediment supply of similar median size thus leading to continuous channel enlargement.

Stream bed dynamics have been identified as a key geomorphic process in lotic habitats (Vericat et al., 2008). The variation in the force of friction acting on the benthos as water moves influence the particle entrainment patterns, which in turn drive the channel form evolution. Whilst this is expected, increased sediment loads of greater particle size (coarser than median particle size) could reduce entrainment potential and thus channel degradation. Bed dynamics have a key role in the distribution of benthic animals and plants through ecological disturbance (Townsend et al., 1997b; Bond, 2004).

\subsection{Influence on SSWH availability}

The combination of simplified channel form and flow regime results in limited SSWH availability. While SSWH area was maximized under low flow conditions, its availability diminished rapidly per-unit flow increase, even for relatively small increases in flow for in the urban channel. The confined U-shaped channel form with relatively flat bed presents less variability in flow depth, which means a steeper increase in depth and velocity as flow increases. Jacobson et al. (2009) emphasized that channel simplification significantly reduced SSWH relative to that present in complex channels. On the other hand, the natural channel morphology maintained consistent patterns of SSWH availability regardless of flow regime, with a similar sequence of availability occurring for different hydroperiods. Here, channel variability allowed high rates of increase in SSWH area as flow increased. The dynamism in the channel depth, with higher extensive lateral bars allowed more surfaces to be inundated 
with shallow-low velocity waters as flow increased thereby resulting in larger areas of SSWH. Thus, topographic variability enables hydrologic variability to provide urban habitat benefits by presenting suitable landforms over a range of flows, compared to simplified plane channel that provide habitat at a single base flow.

The relatively large availability of SSWH occurring in the natural reach, even given urban hydrology with frequent storm flows, has important habitat implications for the life stages of many biota (Mellin et al., 2007; Vietz et al., 2013). In urban catchments where streams experience frequent elevated flows (Walsh et al., 2012), the decreased availability of SSWH can persist for extended periods, eliminating rearing and breeding habitat and refuge. This can impact the production and survival of large numbers of biota such as fish, zooplankton and microinvertebrate populations (Ward \& Stanford, 1995; Freeman et al., 2001; Nielsen et al., 2010) as well as organic matter retention processes (Vietz et al., 2013). SSWH habitats are a primary habitat within natural aquatic systems (Cooper et al., 1997).

Along with total duration, the frequency of larger SSWH area was substantially greater in the natural channel with greater variation in values. While this is closely linked to the increased frequency of peak flows in the urban hydrology, the results of the urban hydrology in natural channel indicate that channel morphology plays a dominant role in the flow-habitat relationship. In other words, morphologically intact channels, even under altered high-flow regime may provide considerable SSWH habitat. Bowen et al. (2003) observed that modified reaches of the Upper Yellowstone River experienced smaller areas of suitable habitat relative to the unmodified reaches.

\subsection{Influence on floodplain inundation}

The findings from the inundation regimes suggest a substantial decreased in the frequency of inundation in the urban reach. While annual urban hydrology generally showed frequent high-magnitude storm flows, the increased channel capacity would require extremely high, non-frequent occurring flows for considerable floodplain inundation. Even for flood flows that were enough to overtop the banks, floodplain inundation was not extensive. Less floodplain surface was inundated by relatively high magnitude-frequent flows compared to 
the natural reach. This was also in part due to the limited floodplain space, typical of confined incised stream reaches (Grant \& Swanson, 1995; Vietz et al., 2015). In addition, under a natural flow regime, modified channels will experience a very low frequency of floodplain inundation. This altered timing of inundation pulse could potentially impact biota (Hamilton et al., 2002). Water flux and associated materials (e.g. nutrients, sediment) between a channel and its floodplain are known to be key driver for a range of ecological and geomorphic processes (Kingsford, 2000; King et al., 2003).

In contrast, a relatively large extent of channel bank is overtopped even for flows just above the $\mathrm{Q}_{\mathrm{bkf}}$ in the natural reach. The natural reach also showed high sensitivity to altered flow regime, such that a large reduction of inundation extent is experienced per unit reduction in flow. Similar results were observed by Cienciala and Pasternack (2017) on the lower Yuba River, California; the authors suggested that reaches with increased rates in inundation per unit flow will likely show high sensitivity to alterations of flow regime.

Our scenarios indicated that the duration of floodplain inundation is reduced in the urban reach compared to the natural reach. We suggest that this is closely linked to the flashiness of flood flows in the urban reach, as floodplain inundation regime is a function of streamflow regime (Dutterer et al., 2013). The ramification of the flashiness of high flow events mean overbank flow is short-lived. In addition, the geomorphic controls associated with limited floodplain space and confined valley walls magnify the decreased duration (Cienciala \& Pasternack, 2017). This was however not the case in the natural reach, even with urban hydrology that increased inundation extent for a larger proportion of time. This revealed the importance of not only flow regime alterations but also morphological alteration, for floodplain connectivity.

\subsection{Implications for stream ecosystems and management of urban streams}

Recent studies (e.g., Wohl et al., 2015; Yarnell et al., 2015; Stone et al., 2017) have argued that environmental flow investigations need to go beyond hydrologic assessment and incorporate hydrogeomorphic processes relevant for aquatic ecosystem health. Our study provides an important step in support of this argument in that it demonstrates how stream 
hydraulic dynamics can be influenced by the compounding contribution of stream channel topography and hydrological regimes. We showed how certain aspects of stream hydraulics which are important for stream ecosystem's health and biodiversity are impacted by these two drivers.

The findings in this study showed that both hydrological regime and channel form modification play a key role in altering the hydraulic regime. Regular physical habitat adjustment is expected with frequent movement of surface sediments, which mobilizes the subsurface particles and the biota that lives in them (Bond, 2004) as well as serve as precursor to channel incision (Hawley et al., 2012). Persistent benthic disturbance, combined with lack of peripheral habitat will reduce the chance of biota finding refugia (Oldmeadow et al., 2010) and eventually lead to loss of sensitive biota (Walsh et al., 2005a). This potentially becomes a key driver of local extinction and declined diversity and abundance of biota. In addition, the changes to the inundation pattern leads to altered seasonal variability and timing of lateral hydrologic connectivity, affecting recruitment and survival of instream biota (Fisher et al., 2007).

Combined, the results of the examined scenarios suggest that hydraulic conditions are highly sensitive to channel morphology. With regards to the role of channel morphology, we have highlighted here that changes to some key aspects (i.e. frequency, duration, magnitude) of hydraulic conditions alterations were magnified by an urban channel form. Bed movement potential in the modified reach was high even for natural flow regime. Habitat retention in a modified channel and lateral hydrological connectivity dynamics were mostly driven by the channel topography. However, our inference that hydraulic conditions are largely sensitive to the channel morphology should not be considered as a conclusion diminishing the value of achieving a natural flow regime through mitigation of stormwater impacts.

Indeed, any self-regeneration by the stream is only plausible if we first address the hydrology (Walsh et al., 2012). It is argued that adjusting individual instream components (e.g. channel modification) is unlikely to be self-sustaining unless catchment scale processes (e.g. hydrological and sediment management) are managed (Booth, 2005; Vietz et al., 2016). 
We suggest that channel morphology must be protected to the greatest extent possible from urbanization-induced changes. If this is not done, future efforts to restore the hydrologic regime may fail to address the negative influence on the hydraulic environment wrought by the altered channel form. In other words, without a natural-like morphology, the natural hydrologic regime pulses will not lead to natural hydraulic processes, particularly those that support ecological functioning of streams. This then limits the efficacy of just restoring the flow regime. In addition, ecosystem conditions are controlled by multi-scalar (e.g. catchment, reach, segment) processes influencing natural ecosystem functions such as flow and sediment regimes, floodplain and habitat dynamics and biota (Beechie et al., 2010). This creates a hysteresis effect, whereby addressing the catchment-scale drivers (specifically flow) will not necessarily solve the site-scale problem without accompanying channel restoration.

The most important management priority in areas that are yet to be urbanised is to protect them, at all costs, from channel degradation. Failure to do so will require very expensive later interventions to simultaneously address the morphological and hydrological impacts of urbanisation. One exception to this will be channels, such as those made of basaltic bedrock, which are likely to resist significant channel change as the flow regime changes.

Restoration efforts, once both the flow and channel are changed, will require an integrated approach. For instance, there may be opportunities to accompany catchment-scale flow mitigation works with promotion of self-regeneration of stream morphology including sediment seeding and the stream self-organising sediments (Wilcock, 2012; MacVicar et al., 2015) to minimize erosion and mobility. In other cases, direct intervention to modify the channel morphology may need to accompany the flow mitigation effort.

\section{CONCLUSIONS}

The hydraulic condition template of an aquatic ecosystem is determined by the interaction of the channel morphology and flow regime. This study used 2D hydraulic model simulations to explore and demonstrate the relative contribution of channel morphology and flow regimes interaction. We evaluated the interaction between these two factors using three ecologically 
relevant hydraulic metrics that addressed channel bed disturbance, habitat retention and floodplain inundation regime.

The results indicated a substantial altered hydraulic regime in the urban conditions compared to the natural. Modelled scenarios showed the limiting effect of the channel morphology in determining the hydraulic conditions. Natural channel morphology reduced the bed disturbance potential of urban flows and showed substantial habitat (SSWH) availability and likely extended periods of lateral connections between the stream and its floodplain regardless of flow regime. This suggests that restoration efforts that aim to achieve a nearnatural hydraulic regime by only targeting a natural hydrologic regime without returning near-natural channel morphology will have limited ecological benefits. We therefore propose that to maintain hydraulic conditions levels likely to sustain healthy ecosystem, a complete management approach should include actions that aims to restore critical processes occurring at different scales. Most importantly, the form of natural channels which are likely susceptive to flow-induced degradation should be protected at all costs, because future management options will be limited by the "legacy effect" of a changed channel.

\section{ACKNOWLEDGEMENTS}

This work was funded by University of Melbourne Research Scholarship and the Melbourne Waterway Research Practice Partnership, supported by Melbourne Water. We owe special thanks to Peter Poelsma, Robert James, and Sarah Fischer of the Waterway Ecosystem Research Group of the University of Melbourne who assisted with field work. We thank Upula Maheepala from Melbourne Water for providing streamflow data. This paper benefited greatly from comments from anonymous reviewers. T.D Fletcher was supported by ARC project FT100100144 during part of this work.

\section{REFERENCES}

Anim, D. O., Fletcher, T. D., Vietz, G., Pasternack, G., \& Burns, M. J. (2018a). Effect of urbanization on stream hydraulics. River Research and Applications1-14. doi: 10.1002/rra.3293.

Anim, D. O., Vietz, G., Fletcher, T. D., Pasternack, G., \& Burns, M. J. (2018b). Understanding stream habitat to inform management in urban catchment. Paper presented at the Proceedings of the 12th International Symposium on Ecohydraulics, Tokyo, Japan. 
Askarizadeh, A., Rippy, M. A., Fletcher, T. D., Feldman, D. L., Peng, J., Bowler, P., . . . AghaKouchak, A. (2015). From rain tanks to catchments: use of low-impact development to address hydrologic symptoms of the urban stream syndrome. Environmental science \& technology, 49(19), 11264-11280.

Beechie, T., \& Bolton, S. (1999). An approach to restoring salmonid habitat-forming processes in Pacific Northwest watersheds. Fisheries, 24(4), 6-15.

Beechie, T. J., Sear, D. A., Olden, J. D., Pess, G. R., Buffington, J. M., Moir, H., . . Pollock, M. M. (2010). Process-based principles for restoring river ecosystems. BioScience, 60(3), 209-222.

Bernhardt, E. S., \& Palmer, M. A. (2007). Restoring streams in an urbanizing world. Freshwater biology, 52(4), 738-751.

Bernhardt, E. S., \& Palmer, M. A. (2011). River restoration: the fuzzy logic of repairing reaches to reverse catchment scale degradation. Ecological Applications, 21(6), 19261931.

Bernhardt, E. S., Palmer, M. A., Allan, J., Alexander, G., Barnas, K., Brooks, S., . . FollstadShah, J. (2005). Synthesizing US river restoration efforts. science, 308(5722), 636637.

Bond, N. R. (2004). Spatial variation in fine sediment transport in small upland streams: the effects of flow regulation and catchment geology. River Research and Applications, 20(6), 705-717.

Booth, D. B. (2005). Challenges and prospects for restoring urban streams: a perspective from the Pacific Northwest of North America. Journal of the North American Benthological Society, 24(3), 724-737.

Bowen, Z. H., Bovee, K. D., \& Waddle, T. J. (2003). Effects of flow regulation on shallowwater habitat dynamics and floodplain connectivity. Transactions of the American Fisheries Society, 132(4), 809-823.

Brooks, A. J., Haeusler, T., Reinfelds, I., \& Williams, S. (2005). Hydraulic microhabitats and the distribution of macroinvertebrate assemblages in riffles. Freshwater biology, 50(2), 331-344.

Brown, R. A., \& Pasternack, G. B. (2014). Hydrologic and topographic variability modulate channel change in mountain rivers. Journal of Hydrology, 510, 551-564.

Brown, R. A., \& Pasternack, G. B. (2017). Bed and width oscillations form coherent patterns in a partially confined, regulated gravel-cobble-bedded river adjusting to anthropogenic disturbances. Earth Surface Dynamics, 5(1), 1-20.

Brown, R. A., Pasternack, G. B., \& Lin, T. (2016). The topographic design of river channels for form-process linkages. Environmental management, 57(4), 929-942.

Burns, M. J., Fletcher, T. D., Walsh, C. J., Ladson, A., \& Hatt, B. (2013). Setting objectives for hydrologic restoration: from site-scale to catchment-scale. NOVATECH 2013.

Castelli, E., Parasiewicz, P., \& Rogers, J. N. (2011). Use of frequency and duration analysis for the determination of thermal habitat thresholds: application for the conservation of Alasmidonta heterodon in the Delaware River. Journal of Environmental Engineering, 138(8), 886-892.

Chang, H. H. (2008). River morphology and river channel changes. Transactions of Tianjin University, 14(4), 254-262. 
Chin, A., \& Gregory, K. (2009). From research to application: management implications from studies of urban river channel adjustment. Geography Compass, 3(1), 297-328.

Cienciala, P., \& Pasternack, G. (2017). Floodplain inundation response to climate, valley form, and flow regulation on a gravel-bed river in a Mediterranean-climate region. Geomorphology, 282, 1-17.

Clark, J. S., Rizzo, D. M., Watzin, M. C., \& Hession, W. C. (2008). Spatial distribution and geomorphic condition of fish habitat in streams: an analysis using hydraulic modelling and geostatistics. River Research and Applications, 24(7), 885-899.

Clarke, S. J., Bruce-Burgess, L., \& Wharton, G. (2003). Linking form and function: towards an eco-hydromorphic approach to sustainable river restoration. Aquatic Conservation: Marine and Freshwater Ecosystems, 13(5), 439-450.

Cooper, S. D., Barmuta, L., Sarnelle, O., Kratz, K., \& Diehl, S. (1997). Quantifying spatial heterogeneity in streams. Journal of the North American Benthological Society, 16(1), 174-188.

Djekovic, V., Milosevic, N., Andjelkovic, A., Djurovic, N., Barovic, G., Vujacic, D., \& Spalevic, V. (2016). CHANNEL MORPHOLOGY CHANGES IN THE RIVER PESTAN, SERBIA. Journal of Environmental Protection and Ecology, 17(3), 12031213.

Dutterer, A., Mesing, C., Cailteux, R., Allen, M., Pine, W., \& Strickland, P. (2013). Fish recruitment is influenced by river flows and floodplain inundation at Apalachicola River, Florida. River Research and Applications, 29(9), 1110-1118.

Emery, J. C., Gurnell, A. M., Clifford, N. J., Petts, G. E., Morrissey, I. P., \& Soar, P. J. (2003). Classifying the hydraulic performance of riffle-pool bedforms for habitat assessment and river rehabilitation design. River Research and Applications, 19(5-6), 533-549.

Finstad, A., Einum, S., Forseth, T., \& Ugedal, O. (2007). Shelter availability affects behaviour, size-dependent and mean growth of juvenile Atlantic salmon. Freshwater biology, 52(9), 1710-1718.

Fisher, S. G., Heffernan, J. B., Sponseller, R. A., \& Welter, J. R. (2007). Functional ecomorphology: feedbacks between form and function in fluvial landscape ecosystems. Geomorphology, 89(1), 84-96.

Fletcher, T. D., Vietz, G., \& Walsh, C. J. (2014). Protection of stream ecosystems from urban stormwater runoff The multiple benefits of an ecohydrological approach. Progress in Physical Geography, 0309133314537671.

Francoeur, S. N., \& Biggs, B. J. (2006). Short-term effects of elevated velocity and sediment abrasion on benthic algal communities Advances in Algal Biology: A Commemoration of the Work of Rex Lowe (pp. 59-69): Springer.

Freeman, M. C., Bowen, Z. H., Bovee, K. D., \& Irwin, E. R. (2001). Flow and habitat effects on juvenile fish abundance in natural and altered flow regimes. Ecological Applications, 11(1), 179-190.

Gibbins, C., Vericat, D., \& Batalla, R. J. (2007). When is stream invertebrate drift catastrophic? The role of hydraulics and sediment transport in initiating drift during flood events. Freshwater biology, 52(12), 2369-2384. 
Gorski, K., De Leeuw, J. J., Winter, H. V., Vekhov, D. A., Minin, A. E., Buijse, A. D., \& Nagelkerke, L. A. (2011). Fish recruitment in a large, temperate floodplain: the importance of annual flooding, temperature and habitat complexity. Freshwater biology, 56(11), 2210-2225.

Grant, G., \& Swanson, F. (1995). Morphology and processes of valley floors in mountain streams, western Cascades, Oregon. Natural and anthropogenic influences in fluvial geomorphology, 83-101.

Gurnell, A., Lee, M., \& Souch, C. (2007). Urban Rivers: Hydrology, Geomorphology, Ecology and Opportunities for Change. Geography Compass, 1(5), 1118-1137. doi: 10.1111/j.1749-8198.2007.00058.x

Hamilton, S. K., Sippel, S. J., \& Melack, J. M. (2002). Comparison of inundation patterns among major South American floodplains. Journal of Geophysical Research: Atmospheres, 107(D20).

Hawley, R., \& Vietz, G. (2016). Addressing the urban stream disturbance regime. Freshwater Science, 35(1), 278-292.

Hawley, R. J., Bledsoe, B. P., Stein, E. D., \& Haines, B. E. (2012). Channel Evolution Model of Semiarid Stream Response to Urban-Induced Hydromodification1. JAWRA Journal of the American Water Resources Association, 48(4), 722-744.

Humphries, P., Cook, R. A., Richardson, A. J., \& Serafini, L. G. (2006). Creating a disturbance: manipulating slackwaters in a lowland river. River Research and Applications, 22(5), 525-542.

Jacobson, R. B., Johnson III, H. E., \& Dietsch, B. J. (2009). Hydrodynamic simulations of physical aquatic habitat availability for pallid sturgeon in the Lower Missouri River, at Yankton, South Dakota, Kenslers Bend, Nebraska, Little Sioux, Iowa, and Miami, Missouri, 2006-07.

Järvelä, J., \& Helmiö, T. (2004). Hydraulic considerations in restoring boreal streams. Hydrology Research, 35(3), 223-235.

Jorde, K., \& Bratrich, C. (1998). River bed morphology and flow regulations in diverted streams: effects on bottom shear stress patterns and hydraulic habitat. Advances in River Bottom Ecology., 47-63.

Jowett, I. (2003). Hydraulic constraints on habitat suitability for benthic invertebrates in gravel-bed rivers. River Research and Applications, 19(5-6), 495-507.

Kemp, J. L., Harper, D. M., \& Crosa, G. A. (2000). The habitat-scale ecohydraulics of rivers. Ecological Engineering, 16(1), 17-29.

King, A., Humphries, P., \& Lake, P. (2003). Fish recruitment on floodplains: the roles of patterns of flooding and life history characteristics. Canadian Journal of Fisheries and Aquatic Sciences, 60(7), 773-786.

Kingsford, R. T. (2000). Ecological impacts of dams, water diversions and river management on floodplain wetlands in Australia. Austral Ecology, 25(2), 109-127.

Kondolf, G. M., \& Li, S. (1992). The pebble count technique for quantifying surface bed material size in instream flow studies. Rivers, 3(2), 80-87.

Ladson, A. R., Walsh, C. J., \& Fletcher, T. D. (2006). Improving stream health in urban areas by reducing runoff frequency from impervious surfaces. Australian Journal of Water Resources, 10(1), 23-33. 
Lisle, T. E., Nelson, J. M., Pitlick, J., Madej, M. A., \& Barkett, B. L. (2000). Variability of bed mobility in natural, gravel-bed channels and adjustments to sediment load at local and reach scales. Water Resources Research, 36(12), 3743-3755.

Lobera, G., Muñoz, I., López-Tarazón, J., Vericat, D., \& Batalla, R. (2017). Effects of flow regulation on river bed dynamics and invertebrate communities in a Mediterranean river. Hydrobiologia, 784(1), 283-304.

Loperfido, J. V., Noe, G. B., Jarnagin, S. T., \& Hogan, D. M. (2014). Effects of distributed and centralized stormwater best management practices and land cover on urban stream hydrology at the catchment scale. Journal of Hydrology, 519, 2584-2595

MacVicar, B., Chapuis, M., Buckrell, E., \& Roy, A. (2015). Assessing the Performance of instream restoration projects using radio frequency identification (RFID) transponders. Water, 7(10), 5566-5591.

McCabe, D. J., \& Gotelli, N. J. (2000). Effects of disturbance frequency, intensity, and area on assemblages of stream macroinvertebrates. Oecologia, 124(2), 270-279.

McMahon, T., Fenton, J., Stewardson, M., Costelloe, J., \& Finlayson, B. (2002). Estimating discharge at an ungauged site. Australian Journal of Water Resources, 5(1), 113-117.

Mellin, C., Kulbicki, M., \& Ponton, D. (2007). Seasonal and ontogenetic patterns of habitat use in coral reef fish juveniles. Estuarine, Coastal and Shelf Science, 75(4), 481-491.

Mérigoux, S., \& Dolédec, S. (2004). Hydraulic requirements of stream communities: a case study on invertebrates. Freshwater biology, 49(5), 600-613.

Milhous, R. T., \& Nestler, J. (2016). On history of habitat criteria in instream flow studies. Part I. Paper presented at the 11th International Symposium on Ecohydraulics (ISE 2016).

Miller, J. R., \& Kochel, R. C. (2010). Assessment of channel dynamics, in-stream structures and post-project channel adjustments in North Carolina and its implications to effective stream restoration. Environmental Earth Sciences, 59(8), 1681-1692.

Montgomery, D. R., Panfil, M. S., \& Hayes, S. K. (1999). Channel-bed mobility response to extreme sediment loading at Mount Pinatubo. Geology, 27(3), 271-274.

Moriasi, D. N., Arnold, J. G., Van Liew, M. W., Bingner, R. L., Harmel, R. D., \& Veith, T. L. (2007). Model evaluation guidelines for systematic quantification of accuracy in watershed simulations. Transactions of the ASABE, 50(3), 885-900.

Negishi, J., Inoue, M., \& Nunokawa, M. (2002). Effects of channelisation on stream habitat in relation to a spate and flow refugia for macroinvertebrates in northern Japan. Freshwater biology, 47(8), 1515-1529.

Nielsen, D. L., Gigney, H., \& Watson, G. (2010). Riverine habitat heterogeneity: the role of slackwaters in providing hydrologic buffers for benthic microfauna. Hydrobiologia, 638(1), 181.

Oldmeadow, D. F., Lancaster, J., \& Rice, S. P. (2010). Drift and settlement of stream insects in a complex hydraulic environment. Freshwater biology, 55(5), 1020-1035.

Palmer, M. A., Hondula, K. L., \& Koch, B. J. (2014). Ecological restoration of streams and rivers: shifting strategies and shifting goals. Annual review of ecology, evolution, and systematics, 45, 247-269.

Pasternack, G. B. (2008). Spawning habitat rehabilitation: advances in analysis tools. Paper presented at the American Fisheries Society Symposium. 
Pasternack, G. B. (2011). 2D modeling and ecohydraulic analysis: University of California at Davis.

Paterson, A., \& Whitfield, A. (2000). Do shallow-water habitats function as refugia for juvenile fishes? Estuarine, Coastal and Shelf Science, 51(3), 359-364.

Paul, M. J., \& Meyer, J. L. (2001). Streams in the urban landscape. Annual Review of Ecology and Systematics, 333-365.

Sawyer, A. M., Pasternack, G. B., Moir, H. J., \& Fulton, A. A. (2010). Riffle-pool maintenance and flow convergence routing observed on a large gravel-bed river. Geomorphology, 114(3), 143-160.

Shearer, K., Hayes, J., Jowett, I., \& Olsen, D. (2015). Habitat suitability curves for benthic macroinvertebrates from a small New Zealand river. New Zealand journal of marine and freshwater research, 49(2), 178-191.

Smith, A. K. (1973). Development and application of spawning velocity and depth criteria for Oregon salmonids. Transactions of the American Fisheries Society, 102(2), 312-316.

Statzner, B., Gore, J. A., \& Resh, V. H. (1988). Hydraulic Stream Ecology: Observed Patterns and Potential Applications. Journal of the North American Benthological Society, 7(4), 307-360. doi: 10.2307/1467296

Statzner, B., \& Higler, B. (1986). Stream hydraulics as a major determinant of benthic invertebrate zonation patterns. Freshwater biology, 16(1), 127-139.

Stone, M. C., Byrne, C. F., \& Morrison, R. R. (2017). Evaluating the impacts of hydrologic and geomorphic alterations on floodplain connectivity. Ecohydrology.

Strom, M. A., Pasternack, G. B., \& Wyrick, J. R. (2016). Reenvisioning velocity reversal as a diversity of hydraulic patch behaviours. Hydrological Processes, 30(13), 2348-2365.

Syme, W. (2001). TUFLOW-Two \& Onedimensional unsteady flow Software for rivers, estuaries and coastal waters. Paper presented at the IEAust Water Panel Seminar and Workshop on 2d Flood Modelling, Sydney.

Townsend, C. R., Scarsbrook, M. R., \& Dolédec, S. (1997a). The intermediate disturbance hypothesis, refugia, and biodiversity in streams. Limnology and oceanography, 42(5), 938-949.

Townsend, C. R., Scarsbrook, M. R., \& Dolédec, S. (1997b). Quantifying disturbance in streams: alternative measures of disturbance in relation to macroinvertebrate species traits and species richness. Journal of the North American Benthological Society, $16(3), 531-544$.

Vander Laan, J. J., Hawkins, C. P., Olson, J. R., \& Hill, R. A. (2013). Linking land use, instream stressors, and biological condition to infer causes of regional ecological impairment in streams. Freshwater Science, 32(3), 801-820.

Vaughan, I., Diamond, M., Gurnell, A., Hall, K., Jenkins, A., Milner, N., . . . Ormerod, S. (2009). Integrating ecology with hydromorphology: a priority for river science and management. Aquatic Conservation: Marine and Freshwater Ecosystems, 19(1), 113125.

Vericat, D., Batalla, R. J., \& Gibbins, C. N. (2008). Sediment entrainment and depletion from patches of fine material in a gravel-bed river. Water Resources Research, 44(11). 
Vietz, G. J., Rutherfurd, I. D., Fletcher, T. D., \& Walsh, C. J. (2016). Thinking outside the channel: Challenges and opportunities for protection and restoration of stream morphology in urbanizing catchments. Landscape and Urban Planning, 145, 34-44.

Vietz, G. J., Sammonds, M. J., \& Stewardson, M. J. (2013). Impacts of flow regulation on slackwaters in river channels. Water Resources Research, 49(4), 1797-1811.

Vietz, G. J., Sammonds, M. J., Walsh, C. J., Fletcher, T. D., Rutherfurd, I. D., \& Stewardson, M. J. (2014). Ecologically relevant geomorphic attributes of streams are impaired by even low levels of watershed effective imperviousness. Geomorphology, 206, 67-78.

Vietz, G. J., Walsh, C. J., \& Fletcher, T. D. (2015). Urban hydrogeomorphology and the urban stream syndrome Treating the symptoms and causes of geomorphic change. Progress in Physical Geography, 40(3), 480-492.

Violin, C. R., Cada, P., Sudduth, E. B., Hassett, B. A., Penrose, D. L., \& Bernhardt, E. S. (2011). Effects of urbanization and urban stream restoration on the physical and biological structure of stream ecosystems. Ecological Applications, 21(6), 1932-1949. doi: $10.2307 / 41416629$

Wallis, C., Maddock, I., Visser, F., \& Acreman, M. (2012). A framework for evaluating the spatial configuration and temporal dynamics of hydraulic patches. River Research and Applications, 28(5), 585-593.

Walsh, C. J., Booth, D. B., Burns, M. J., Fletcher, T. D., Hale, R. L., Hoang, L. N., . . . Scoggins, M. (2016). Principles for urban stormwater management to protect stream ecosystems. Freshwater Science, 35(1), 398-411.

Walsh, C. J., Fletcher, T. D., \& Burns, M. J. (2012). Urban stormwater runoff: a new class of environmental flow problem.

Walsh, C. J., Fletcher, T. D., \& Ladson, A. R. (2005a). Stream restoration in urban catchments through redesigning stormwater systems: looking to the catchment to save the stream. Journal of the North American Benthological Society, 24(3), 690-705.

Walsh, C. J., Roy, A. H., Feminella, J. W., Cottingham, P. D., Groffman, P. M., \& Morgan II, R. P. (2005b). The urban stream syndrome: current knowledge and the search for a cure. Journal of the North American Benthological Society, 24(3), 706-723.

Ward, J. V., \& Stanford, J. (1995). Ecological connectivity in alluvial river ecosystems and its disruption by flow regulation. River Research and Applications, 11(1), 105-119.

Wenger, S. J., Roy, A. H., Jackson, C. R., Bernhardt, E. S., Carter, T. L., Filoso, S., . . . Martí, E. (2009). Twenty-six key research questions in urban stream ecology: an assessment of the state of the science. Journal of the North American Benthological Society, 28(4), 1080-1098.

Wheaton, J. M., Pasternack, G. B., \& Merz, J. E. (2004). Spawning habitat rehabilitation-I. Conceptual approach and methods. International Journal of River Basin Management, 2(1), 3-20.

Wilcock, P. R. (2012). Stream Restoration in Gravel-Bed Rivers. Gravel-Bed Rivers: Processes, Tools, Environments, 135-149.

Wohl, E., Bledsoe, B. P., Jacobson, R. B., Poff, N. L., Rathburn, S. L., Walters, D. M., \& Wilcox, A. C. (2015). The natural sediment regime in rivers: broadening the foundation for ecosystem management. BioScience, 65(4), 358-371. 
Yarnell, S. M., Petts, G. E., Schmidt, J. C., Whipple, A. A., Beller, E. E., Dahm, C. N., . . . Viers, J. H. (2015). Functional flows in modified riverscapes: hydrographs, habitats and opportunities. BioScience, 65(10), 963-972.

TABLE 1. Characteristics of the selected catchment and study reach

$\begin{array}{ccc} & \text { Urban site } & \text { Natural site } \\ \text { Catchment area }\left(\mathrm{km}^{2}\right) & 67 & 44 \\ \text { Latitude, Longitude } & 38^{\circ} 03^{\prime} 02.34 \square \mathrm{S}, & 38^{\circ} 0^{\prime} 38.35 \square \mathrm{S}, \\ & 145^{\circ} 21^{\prime} 53.42 \square \mathrm{E} & 145^{\circ} 23^{\prime} 1.32 \square \mathrm{E} \\ \text { Total imperviousness cover } & 7.1 & 4.3 \\ (\%) & 3.1 & 0.1 \\ \text { Connected imperviousness } & & \\ {\text { cover }(\%)^{\mathrm{a}}}^{\text {Reach gradient }(\%)^{\mathrm{b}}} & 0.003 & 0.001 \\ \quad \text { Sinuosity } & 1.1 & 1.3 \\ \text { Entrenchment ratio }^{\mathrm{b}} & 1.2 & 1.9 \\ \text { Mean bankfull depth }(\mathrm{m})^{\mathrm{b}} & 1.6 & 0.84 \\ {\text { Mean bankfull width }(\mathrm{m})^{\mathrm{b}}}^{\text {Mean }} & 7.02 & 4.10\end{array}$


Reach bankfull discharge

$$
\left(\mathrm{m}^{3} / \mathrm{s}\right)
$$

${ }^{a}$ The proportion of total imperviousness cover connected to the stream via conventional stormwater drainage systems

${ }^{b}$ Estimates from field survey data

Figure Legends

Figure 1. The study sites located on the Cardinia Creek draining the Cardinia Shire catchment in Victoria, Australia flowing south into the Western Port Bay

Figure 2. Daily streamflow hydrograph for the urban and natural reach during the study period. The inset show the mean of the daily streamflow data for each year.

Figure 3. Schematic of the hydrogeomorphic scenarios investigated. Curb and Cnat represent the urban and natural channel respectively. Qurb and Qnat represent the urban and natural hydrology respectively See text for scenarios acronyms definitions.

Figure 4. Time series of the daily maximum (95th percentile) Shield stress for the two study reaches for each scenario. (a) urban (CurbQurb) and natural (CurbQnat) flow regimes in the urban channel and (b) urban (CnatQurb) and natural (CnatQnat) flow regimes in the natural channel. Solid horizontal black line shows the critical Shields stress

Figure 5. Continuous duration (in days) above Shields stress threshold differences of the modelled scenarios over the study period

Figure 6. Time series of the daily total SSWH area available per $100 \mathrm{~m}$ of reach for the two study reaches for each scenario. (a) urban (CurbQurb) and natural (CurbQnat) flow regimes in the urban channel and (b) urban (CnatQurb) and natural (CnatQnat) flow regimes in the natural channel.

Figure 7. Distribution of SSWH area daily values for the study period data for each modelled scenario 
Figure 8. Floodplain inundation time series for the two study reaches for each scenario. (a) urban (CurbQurb) and natural (CurbQnat) flow regimes in the urban channel and (b) urban (CnatQurb) and natural (CnatQnat) flow regimes in the natural channel.

Figure 9. (a) Continuous duration of floodplain inundation events and (b) frequency (number of days) of floodplain inundation occurrence for each scenario for the study period. 


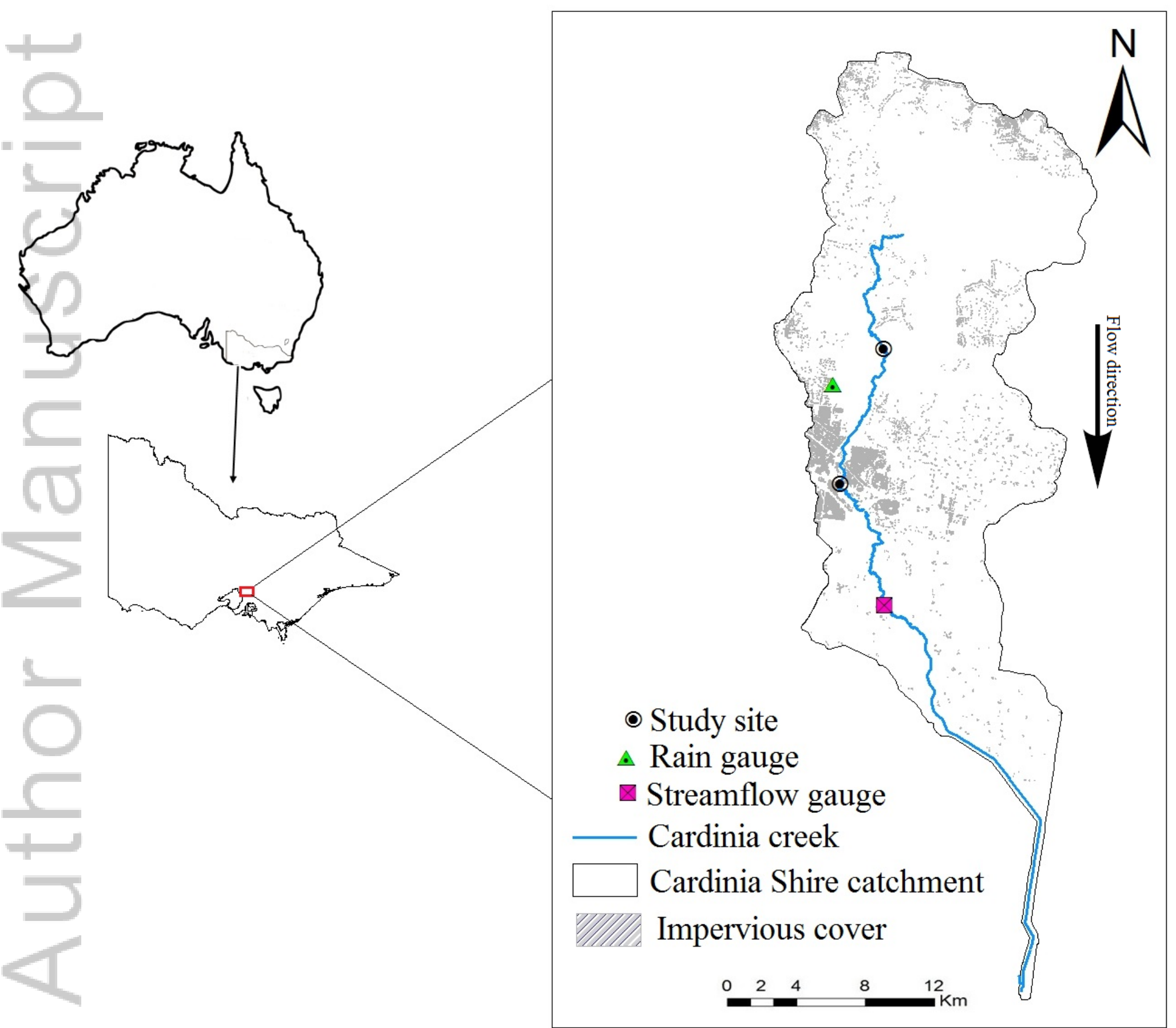

ECO_2050_f1.tif 


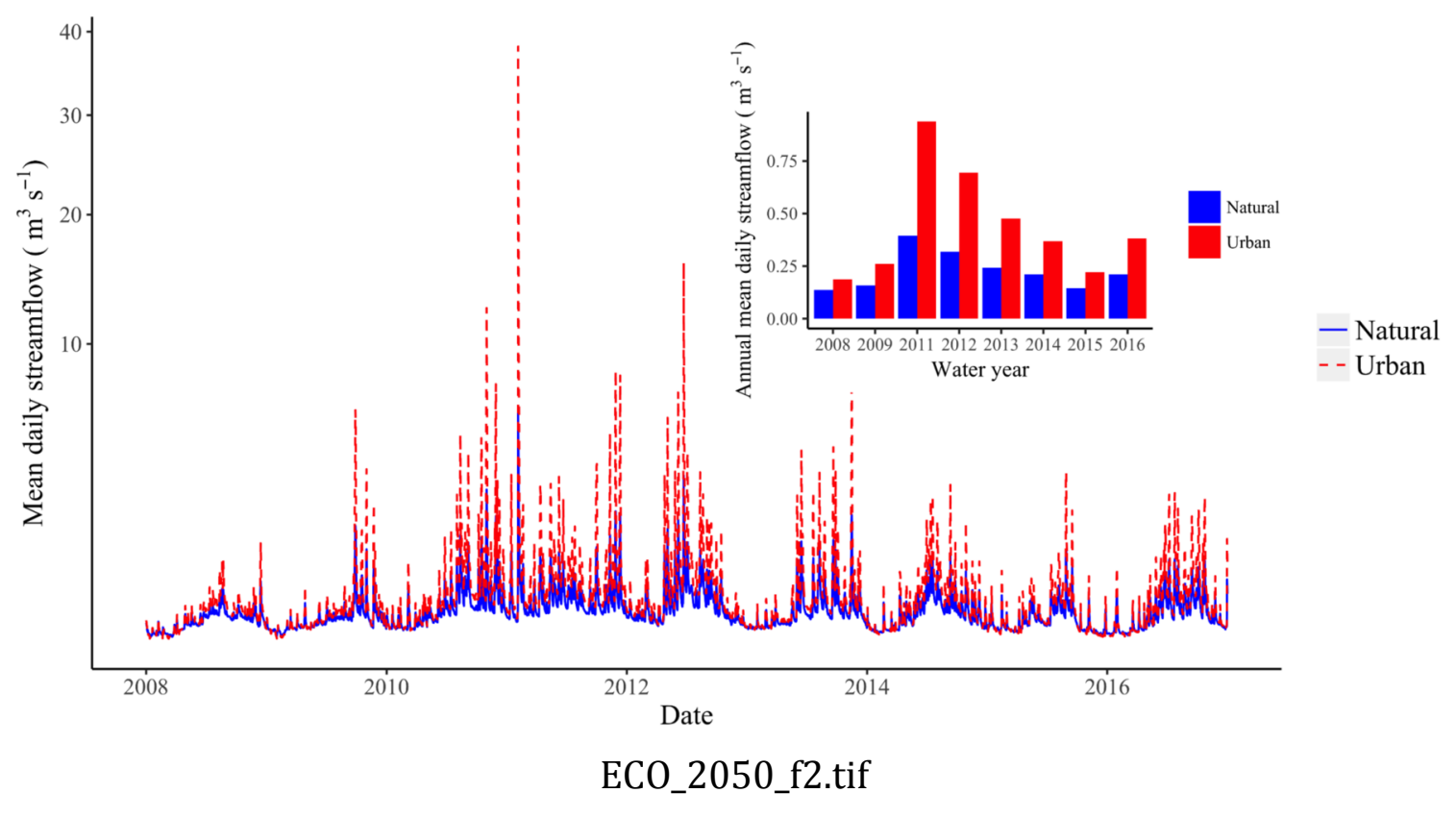

This article is protected by copyright. All rights reserved. 


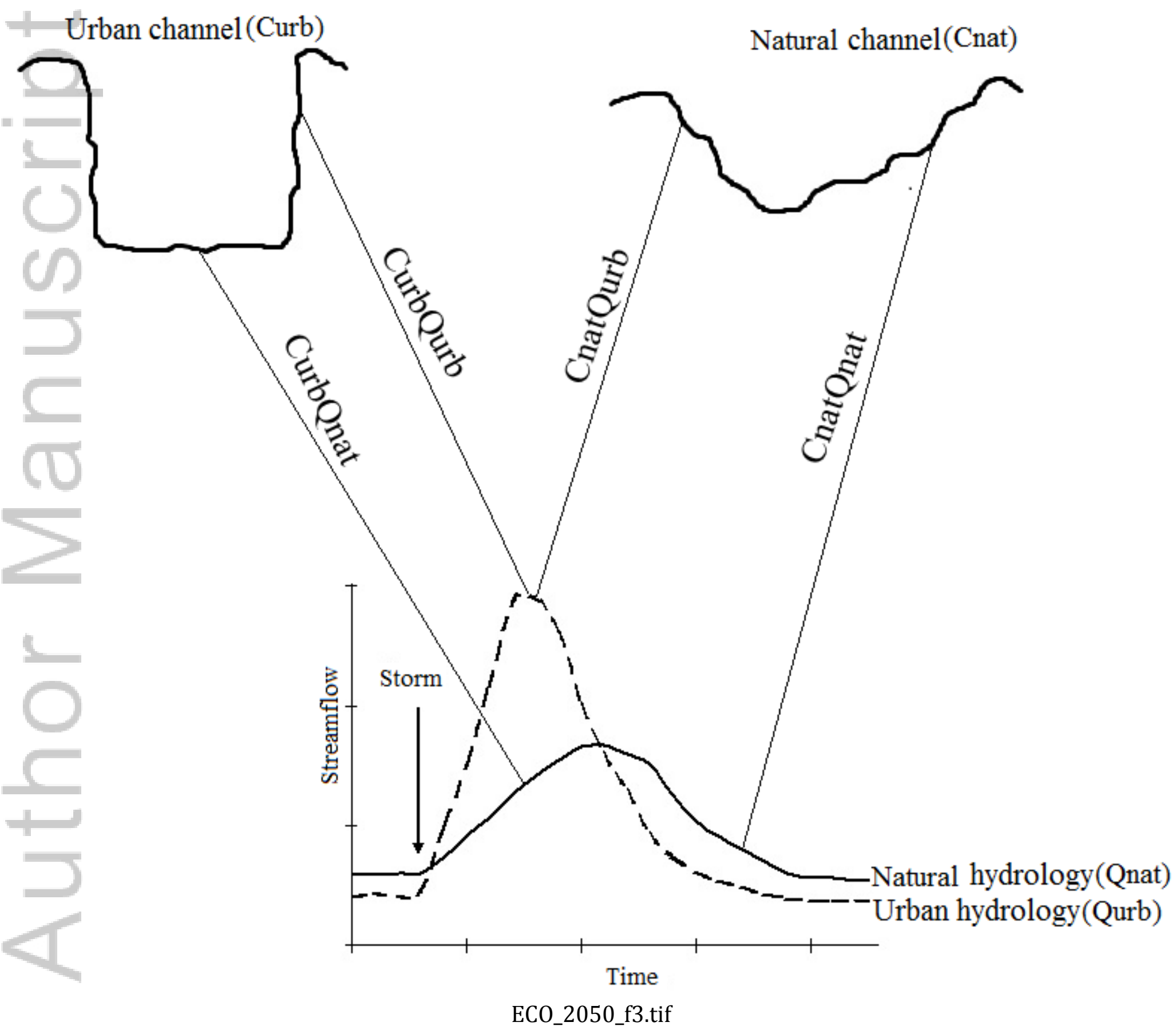


(a)

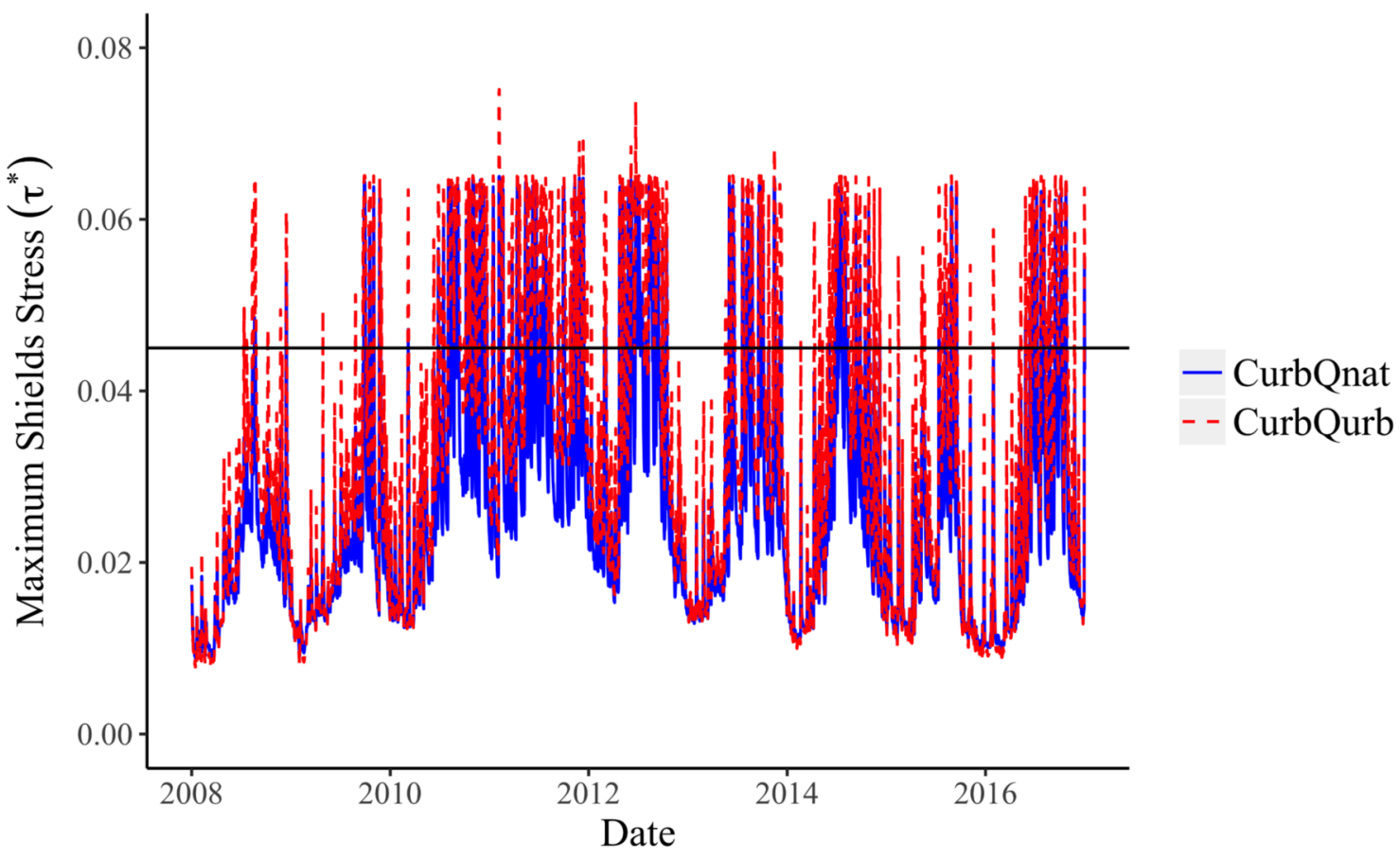

(b)

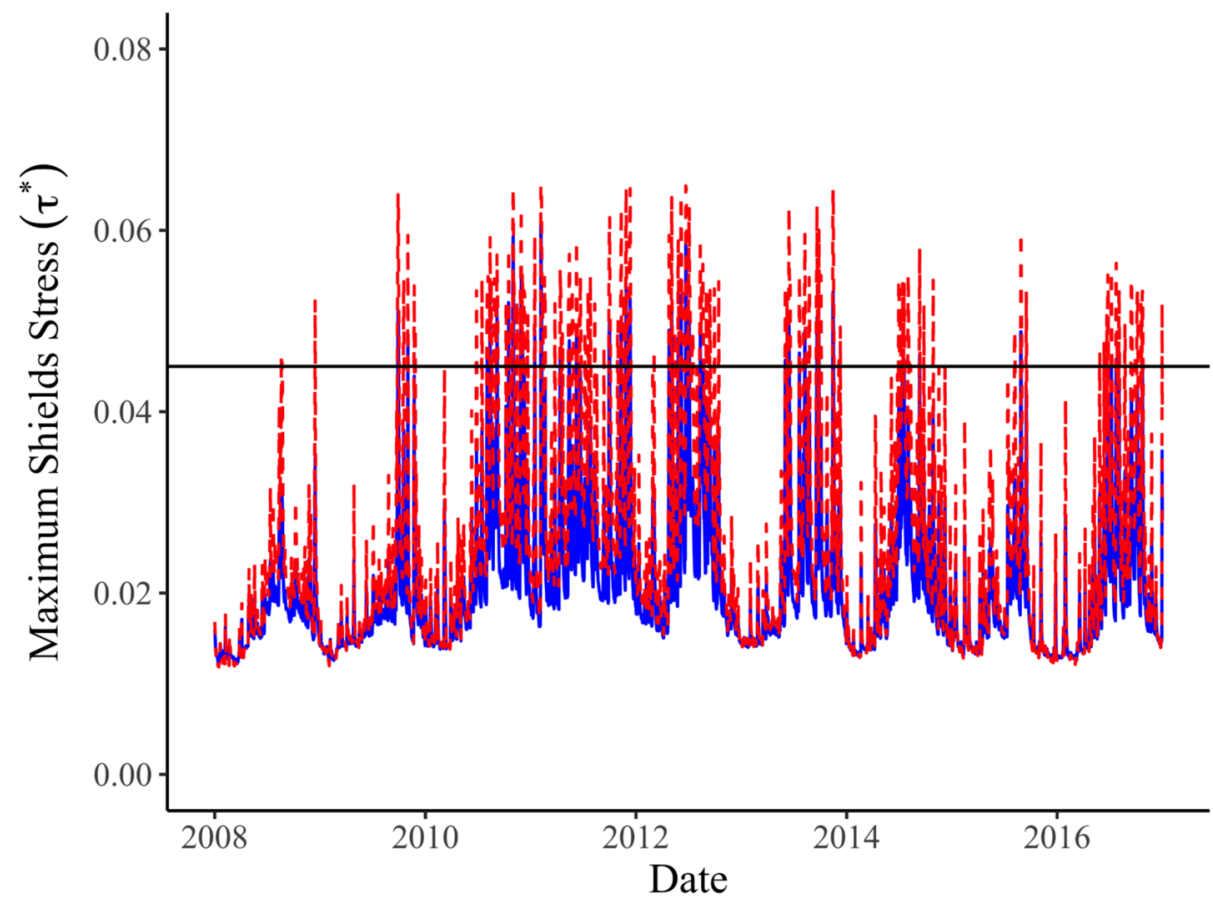

- CnatQnat

- - CnatQurb

ECO_2050_f4.tif

This article is protected by copyright. All rights reserved. 


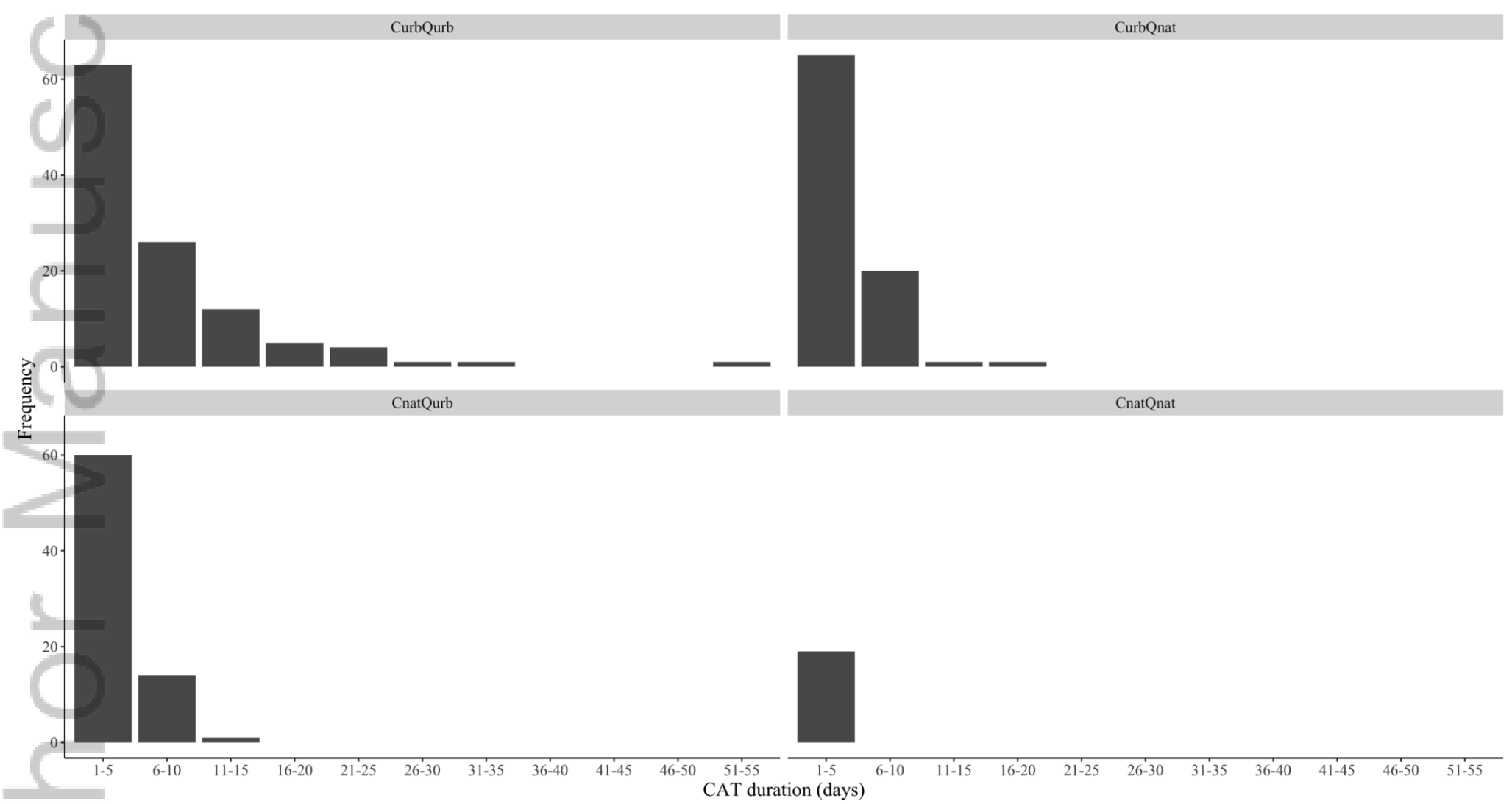

ECO_2050_f5.tif

This article is protected by copyright. All rights reserved. 
(a)

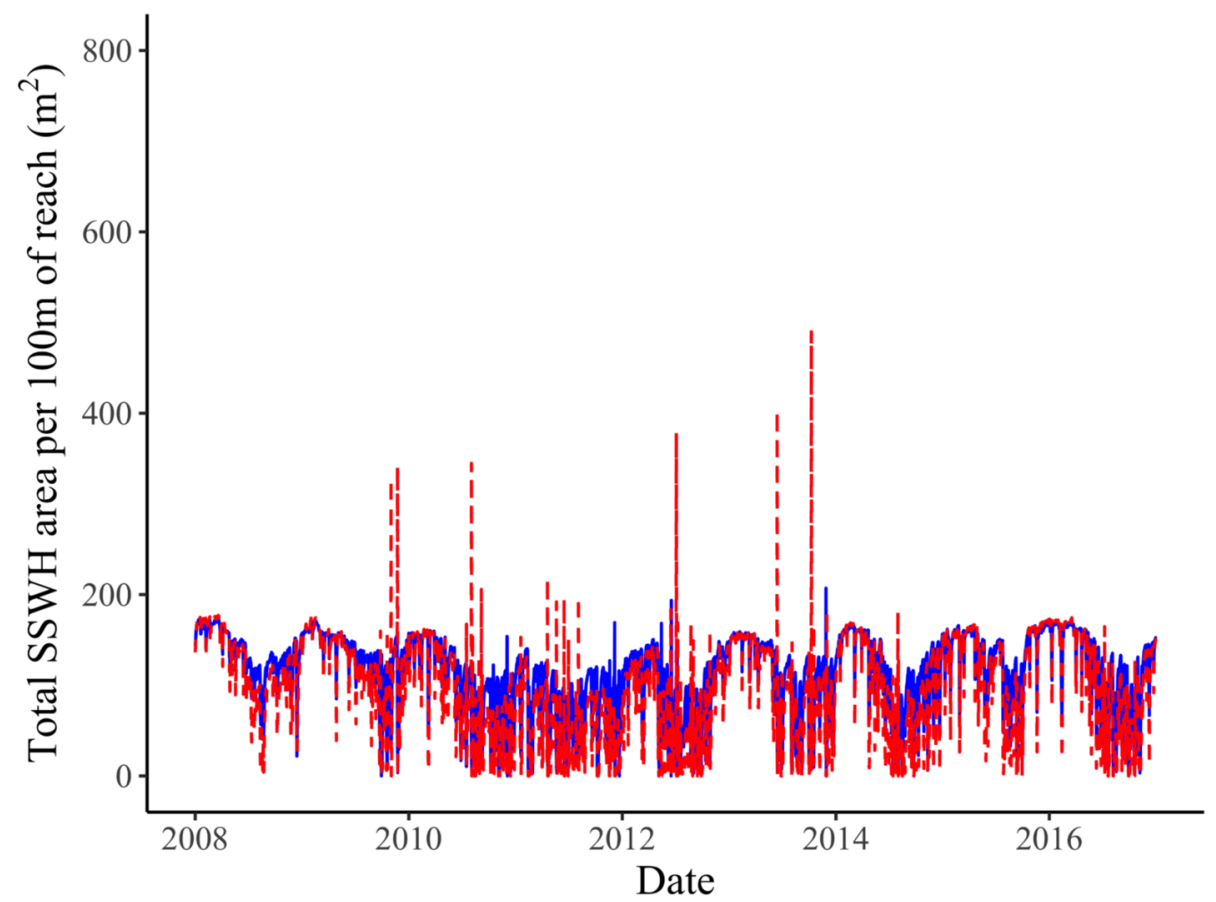

(b)

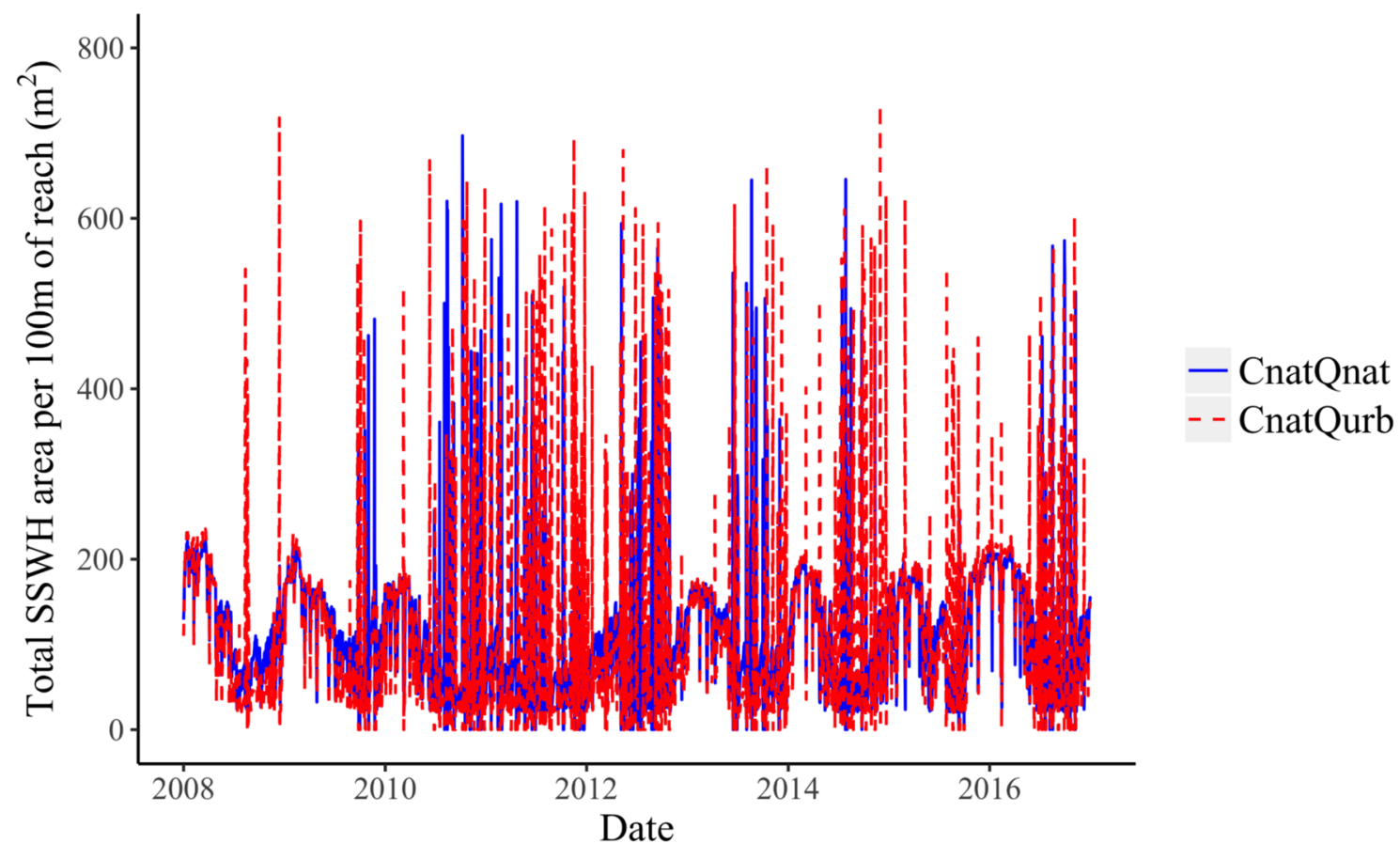

ECO_2050_f6.tif 
(a)

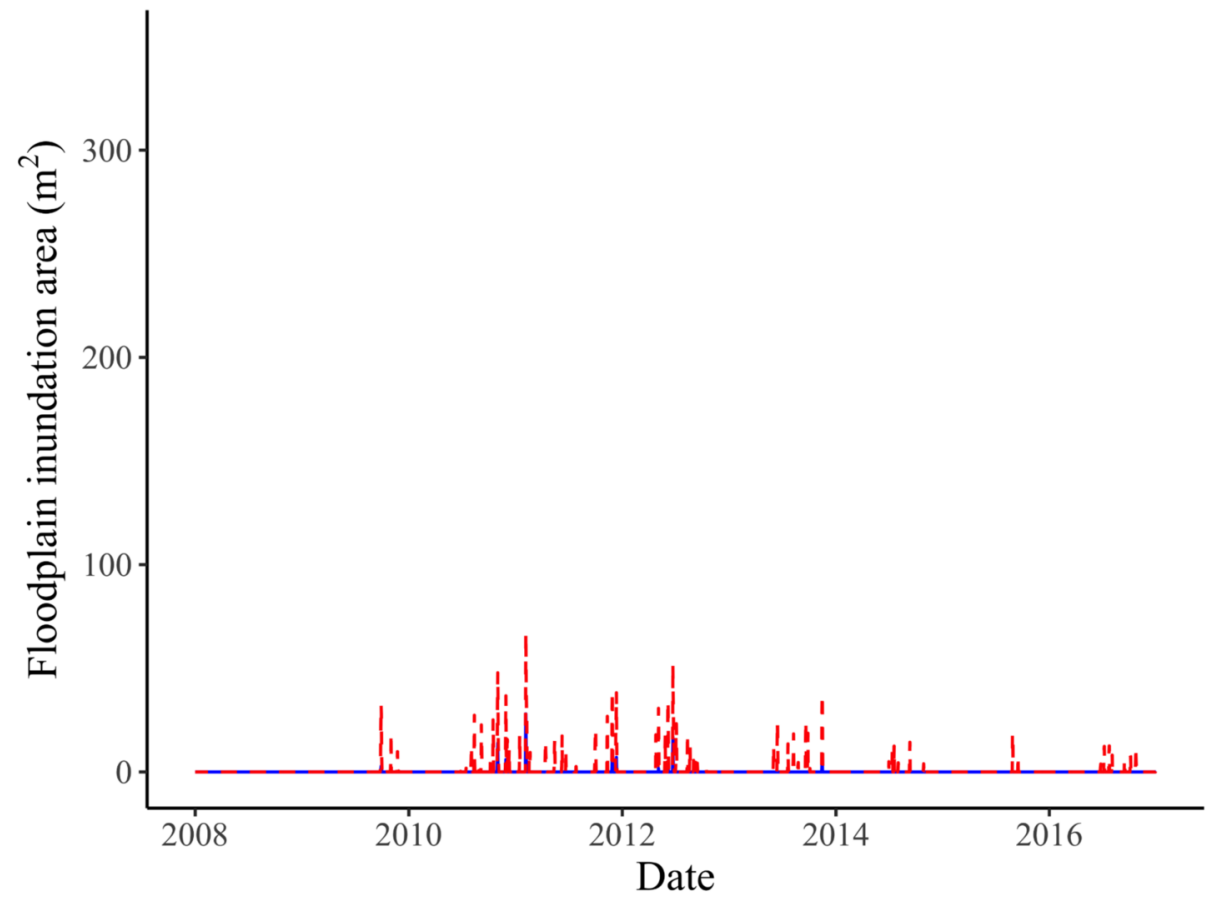

(b)

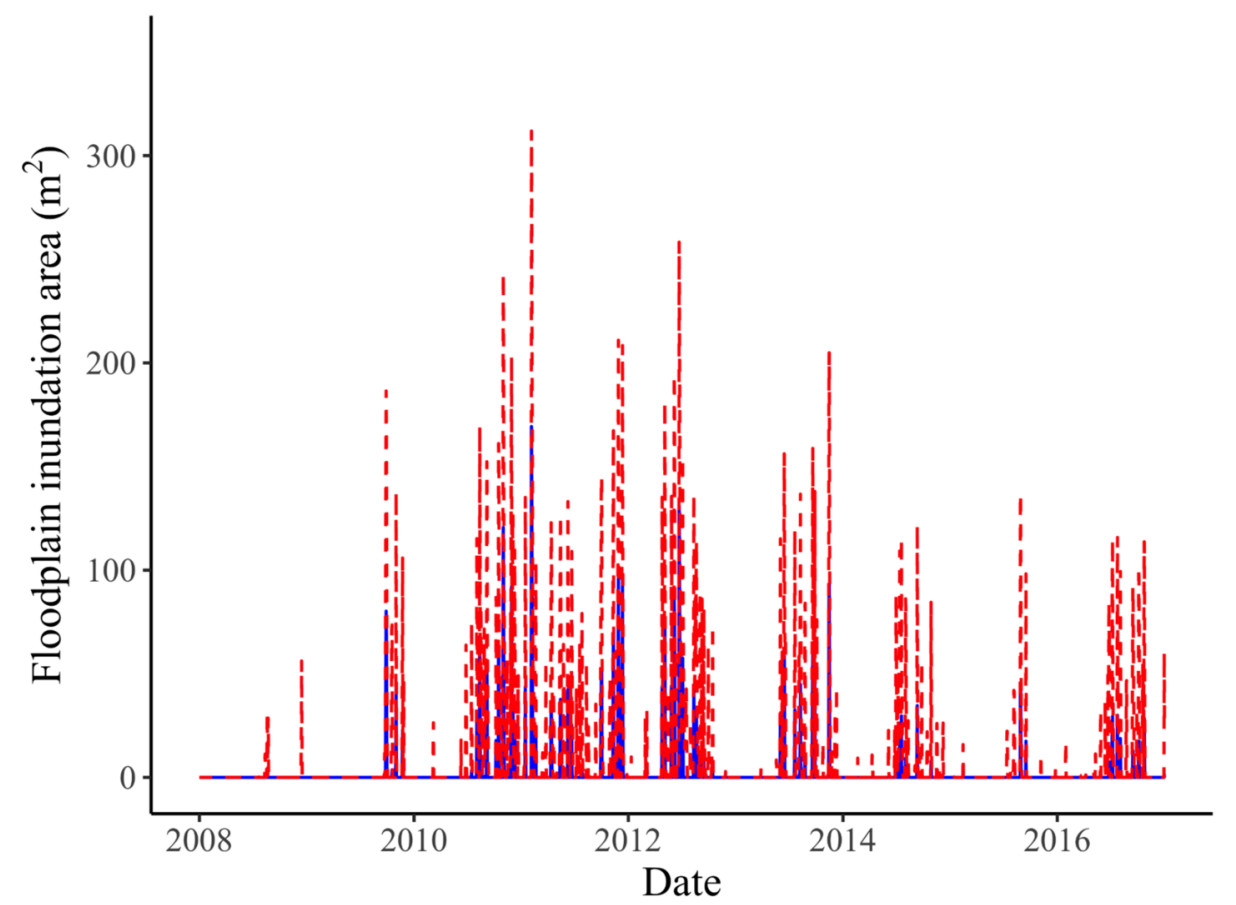

ECO_2050_f8.tif 
(a)

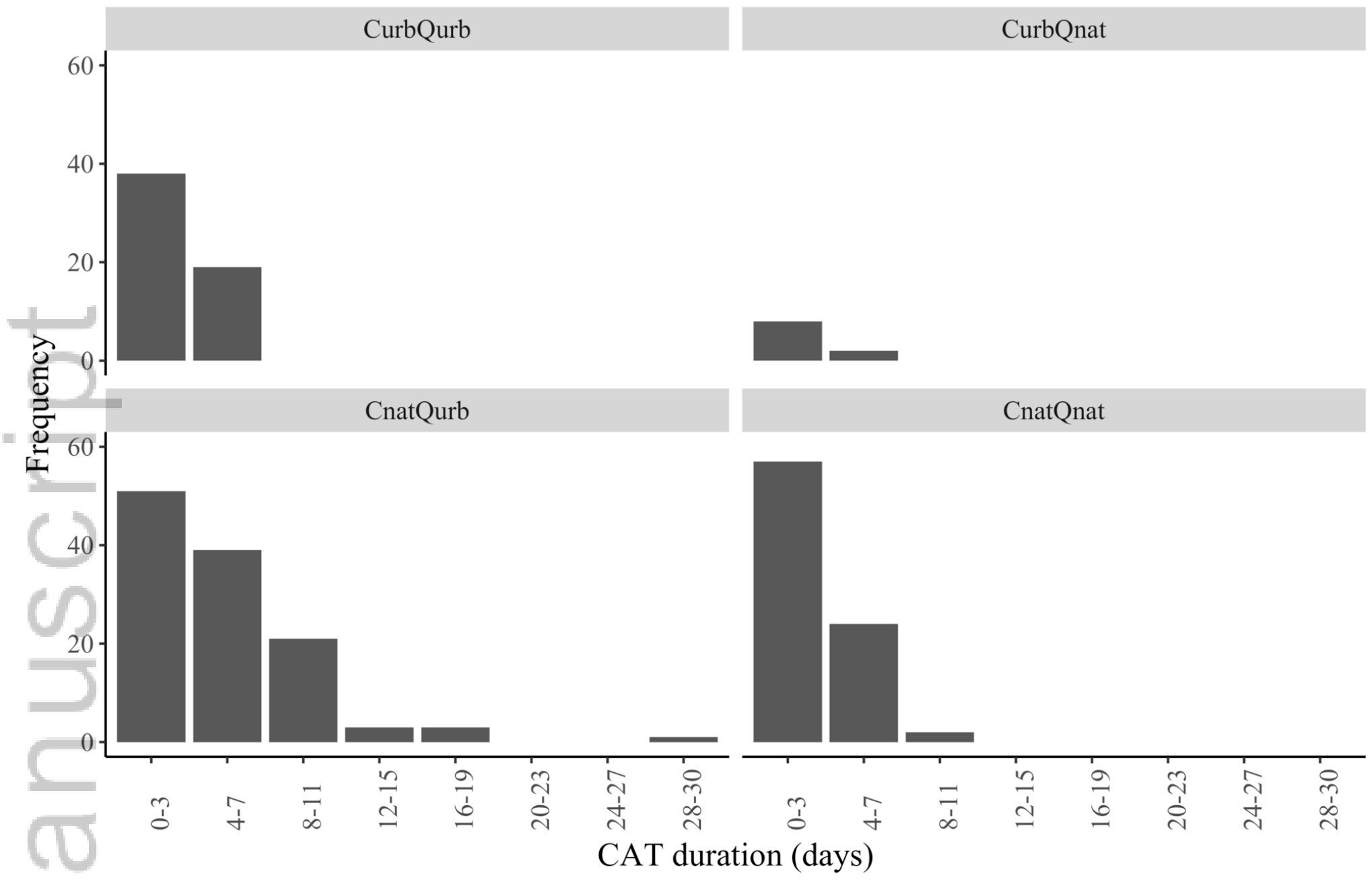

(b)

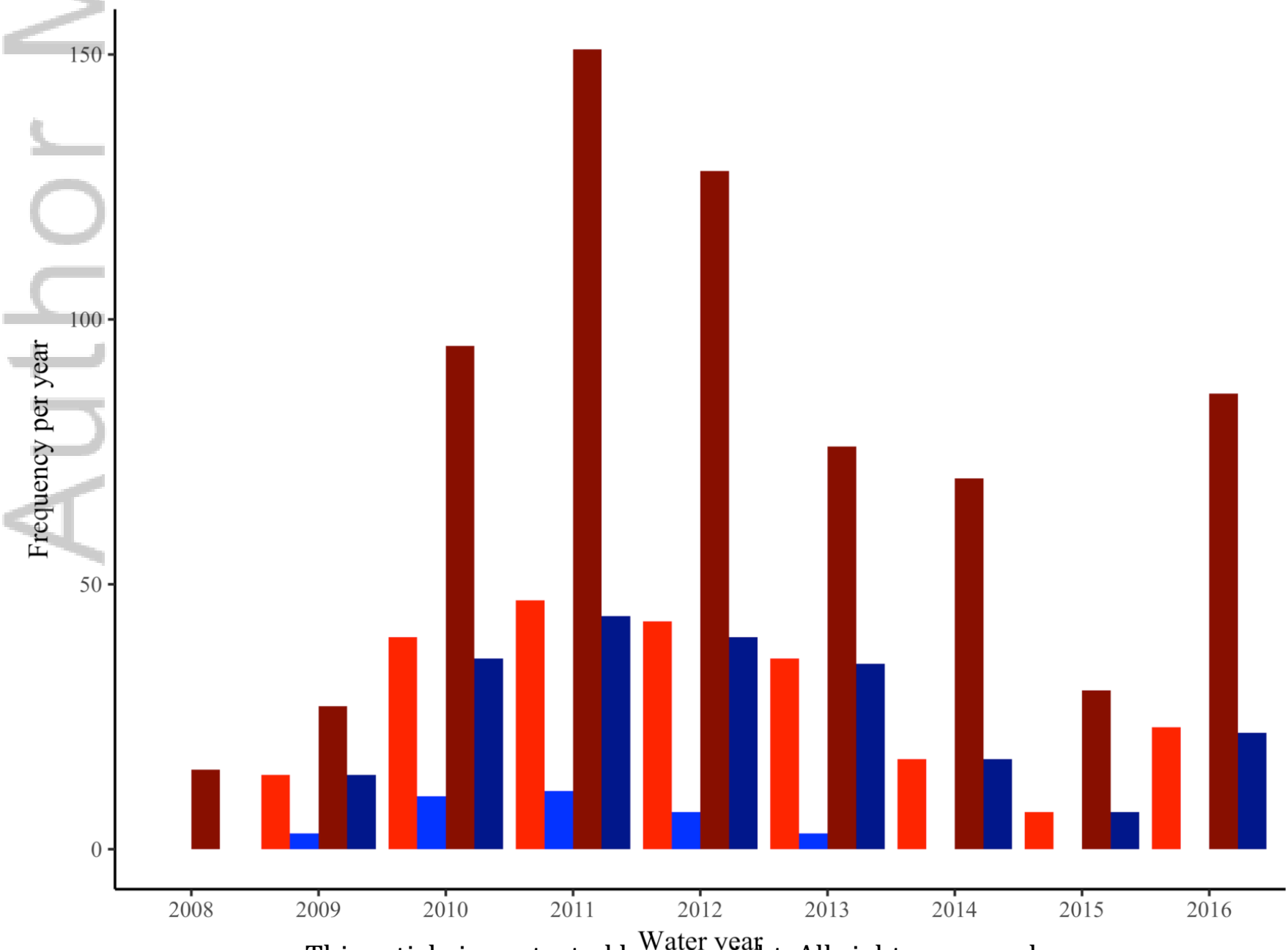

This article is protected by copyright. All rights reserved. 


\section{University Library}

\section{- M M N E R VA A gateway to Melbourne's research publications}

Minerva Access is the Institutional Repository of The University of Melbourne

Author/s:

Anim, DO;Fletcher, TD;Vietz, GJ;Pasternack, GB;Burns, MJ

Title:

Restoring in-stream habitat in urban catchments: Modify flow or the channel?

Date:

2019-01-01

Citation:

Anim, D. O., Fletcher, T. D., Vietz, G. J., Pasternack, G. B. \& Burns, M. J. (2019). Restoring in-stream habitat in urban catchments: Modify flow or the channel?. ECOHYDROLOGY, 12 (1), https://doi.org/10.1002/eco.2050.

Persistent Link:

http://hdl.handle.net/11343/284707 